WIDER Working Paper 2018/32

\title{
The tipping point
}

The impact of rising electricity tariffs on large firms in South Africa

Angelika Goliger ${ }^{1}$ and Landon McMillan ${ }^{2}$

March 2018 
Abstract: While much research has been done on the economic impacts of load-shedding in South Africa, fewer studies have focused on the effects of the rapidly rising electricity tariffs. The issue of tariff increases has now become even more critical, with technological developments making it easier and cheaper for consumers to reduce their demand for grid-based electricity. There have been some South African studies that have attempted to estimate the price elasticity of electricity demand or to show vulnerable sectors, but all have struggled to demonstrate the potential impacts on the competitiveness of individual firms and their decisions to invest in their own generation, and the longer-run impacts on electricity demand. This study examines the timing and type of own-generation investment decisions that are viable for 21 large companies, and the likely impact of this on South Africa's electricity utility.

Keywords: net present value, own-generation, elasticity of demand, investment, firm profitability JEL classification: D22, D25, L51, L94

Acknowledgements: The authors would like to thank Wian Boonzaaier and Konstantin Makrelov.

Disclaimer: The views expressed in this paper are the personal views of the authors and do not represent those of the National Treasury, South African Revenue Services, or Government of the Republic of South Africa. While every precaution is taken to ensure the accuracy of information, the National Treasury shall not be liable to any person for inaccurate information, omissions, or opinions contained herein.

\footnotetext{
${ }^{1}$ National Treasury, Pretoria, South Africa, corresponding author: angelika.goliger@treasury.gov.za; ${ }^{2}$ Ministry of Business, Innovation and Employment, Wellington, New Zealand (previously National Treasury, Pretoria, South Africa)

This study has been prepared within the UNU-WIDER project 'Southern Africa-Towards inclusive economic development (SATIED)'.
}

Copyright (C) UNU-WIDER 2018

Information and requests: publications@wider.unu.edu

ISSN 1798-7237 ISBN 978-92-9256-474-2 https://doi.org/10.35188/UNU-WIDER/2018/474-2

Typescript prepared by Merl Storr.

The United Nations University World Institute for Development Economics Research provides economic analysis and policy advice with the aim of promoting sustainable and equitable development. The Institute began operations in 1985 in Helsinki, Finland, as the first research and training centre of the United Nations University. Today it is a unique blend of think tank, research institute, and UN agency — providing a range of services from policy advice to governments as well as freely available original research.

The Institute is funded through income from an endowment fund with additional contributions to its work programme from Finland, Sweden, and the United Kingdom as well as earmarked contributions for specific projects from a variety of donors.

Katajanokanlaituri 6 B, 00160 Helsinki, Finland

The views expressed in this paper are those of the author(s), and do not necessarily reflect the views of the Institute or the United Nations University, nor the programme/project donors. 
Globally, technological changes have been occurring on multiple fronts in the electricity space: new and cheaper energy generation options, and the rise of distributed generation; improvements in storage technologies; new information systems enabling the Internet of Things and smart grids; new energy-related industry technologies such as electric vehicles, fuel cells, and logistics technologies, amongst others. These developments are resulting in lower electricity prices, as well as new ways for consumers to manage their electricity usage, sell power back into the grid, or become (partly or fully) independent of traditional grid-based electricity. While these developments are positive for electricity consumers, they are challenging for electricity providers with more traditional business models, and can lead to what is known as a utility 'death spiral' (O'Boyle 2017).

In South Africa's case, the electricity sector is dominated by Eskom, a state-owned and integrated electricity provider. Around 90 per cent of the country's electricity is generated by Eskom's coalfired power stations (Eskom n.d.). There is minimal competition in the generation space from independent power producers, which are largely in the renewable space and have to sell power back to Eskom. Eskom has a monopoly on transmission, and also distributes power. Municipalities also act as distributors, accounting for about 40 per cent of electricity sales (Eskom 2017).

Electricity is generally a relatively small proportion of a firm's overall operating expenditure or a household's consumption expenditure, but it is nonetheless critical for the operation of machinery and the running of lights and appliances. Hence firms and individuals were relatively inelastic in their demand patterns when electricity prices were historically low in South Africa before 2008. In addition, the direct prices of alternatives energy sources at the time, and the indirect costs associated with the installation of the necessary infrastructure and the logistics of sourcing and obtaining it, meant there was little or no cross-price elasticity. Essentially, electricity demand was largely determined by the income effect, and for firms by output or value-added growth. However, starting in 2008, electricity prices in South Africa started to rise steeply (Figure 1), changing the relative costs of electricity with respect to alternative energy options and in relation to output prices. This in turn should have made consumers more elastic.

Figure 1: Electricity tariff trends in South Africa

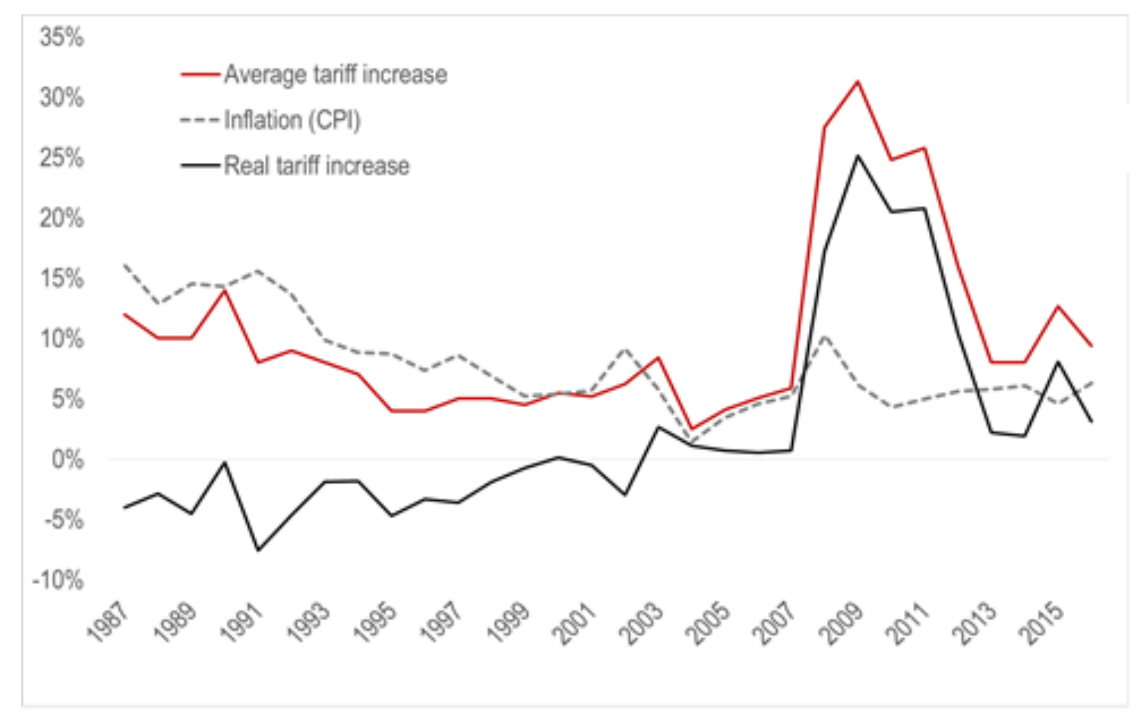

Source: authors' illustration based on data from Eskom (n.d.a) and StatsSA (n.d.). 
The price elasticity of demand for electricity, and the strongly related energy intensity of economic growth, has been difficult to estimate because of the current electricity shortfalls, which artificially constrain the market, thereby masking price elasticity effects. ${ }^{1}$ The timing of the price increases, which largely coincided with an economic recession, also make estimation difficult, as does the lumpy long-term nature of energy-intensive investments. Finally, the quality of data in South Africa, including the availability of municipal data and data disaggregated for sector-specific analysis, is problematic. Nevertheless, anecdotal evidence suggests that steep electricity price increases over recent years, combined with lower economic growth, low commodity prices, generally low inflation rates, and excess productive capacity in many countries around the world, means that many firms are under severe price pressure, and that electricity demand is more elastic.

With rising electricity prices in South Africa, there are a number of possible electricity cost 'tipping points' that might result in firms making decisions that significantly alter their electricity demand profiles, including:

- deciding to generate their own electricity,

- deciding not to invest any further,

- deciding to invest elsewhere in the region or in another sector,

- deciding to invest in large energy efficiency programmes, or

- deciding to shut down one or more parts of their business.

These kinds of decision will have large ramifications for Eskom sales, and for the South African economy more broadly. If firms choose to delay or cancel investment, or indeed to shut plants down, this will affect forecasts not only of economic growth, but also of electricity demand, and of how much supply is required to meet that demand. Whilst decisions to invest in other sectors may not affect growth, they will contribute to structural transformation, and could have an impact on variables such as employment and exports. The decision to build own-generation may be viewed by some in a positive light, as it is better than shutting down facilities and will result in some investment expenditure. However, it could have large impacts on Eskom's revenue, and this in turn could have large implications for the average price level for those still supplied from the grid. Furthermore, it could impact the South African fiscus in terms of Eskom's demands for government guarantees or recapitalization. A decision to invest in energy efficiency is generally viewed in a positive light (despite some potential decline in sales revenue for Eskom) in that firms will become less energy-intensive and potentially more competitive and sustainable, and it will contribute to environmental objectives whilst also contributing to investment expenditure.

This paper attempts to model where and when such tipping points might be reached, using financial information from 21 companies from various sectors in South Africa, cost information for own-generation technologies, and tariff increase scenarios. The literature review that follows highlights relevant research on demand elasticities and the effects of electricity tariff increases on various sectors, and an electricity tipping-point study previously commissioned by Eskom. This is followed by sections that look at the impact of electricity tariff increases on the operating profits of firms used in the study, and the ability of these firms to move their electricity consumption offgrid by investing in their own generation. The paper ends with concluding remarks.

\footnotetext{
${ }^{1}$ For example, Eskom's key industrial customers have been load-curtailed by about 10 per cent from pre-2008 baselines since 2008. From January to June 2015 there was load-shedding on 82 days and for 709 hours, with unserved energy amounting to 1,095 gigawatts.
} 
There have been a few elasticity and sector-level studies related to electricity tariffs in South Africa. Research by Deloitte (2009) tried to calculate the price elasticity of demand for electricity by sector by estimating an error correction model, using detailed sector-level data from Eskom on their key industrial customers. Although the data did not cover residential and commercial customers sufficiently to be considered representative of South Africa, it did cover a significant proportion of most mining and many manufacturing sectors, where Eskom tends to supply large customers directly. The results showed demand to be very inelastic, but the authors argued that there had been insufficient variation in price in the data set to test the price effect sufficiently. A longer-run estimation - based on publicly available data sets-showed more elastic demand responses, with electricity consumption increasing as real prices declined over a period of 20 years, although there are some methodological issues with using this data. ${ }^{2}$

Inglesi and Pouris (2010) used Engle-Granger methodology to model electricity demand with data for 1980-2007, and found that while in the short run firm demand for electricity is influenced by economic and population growth, in the long run income and the price of electricity are larger determinants. Inglesi-Lotz and Blignaut, in their 2011 panel data analysis of various sectors' responses to electricity price increases during 1993-2006, found that the industrial sector had a statistically significant negative price elasticity of demand of -0.869 , whilst other sectors were found not to be sensitive to historical electricity price increases. However, the paper concludes that structural change is expected in economic sectors due to high increases in electricity prices, which may spur sectors to invest in more efficient technologies or other forms of energy that are more affordable.

All these studies recommended that changing levels of elasticity or 'tipping points' should be examined. More recently, Kohler (2013) shows that while price elasticity of demand might have been an inelastic -0.738 for 1989-2009, it has become more elastic. Kohler suggests a long-run elasticity of up to -3.4 for industry.

In their paper on effects of electricity shortages on productivity, Fisher-Vanden et al. (2013) found that in Chinese firms exposed to power shortages there was no indication of an increase in owngeneration in the early 2000s. ${ }^{3}$ However, the generation market has changed substantially since then, and the costs of own-generation have been on the decline (SAPVIA 2013). According to Edwards (2012), higher electricity tariffs encourage innovation in terms of production processes as well as investment in own-generation.

\footnotetext{
${ }^{2}$ Publicly available data from supply use tables shows values in South African rand of electricity outputs consumed as inputs in various sectors. It does not, however, show actual volume in kilowatt-hours consumed, and average electricity prices vary greatly between sectors. It is possible to get broad categories of electricity sales by value and volume using Eskom's high-level categorization: mining, manufacturing, rural, resellers, traction, commercial, residential.

${ }^{3}$ In the Manufacturing Circle's review for the second quarter of 2015, ongoing electricity supply challenges were widely identified as a key concern for manufacturers, with load-shedding, supply uncertainty, and rising electricity tariffs having an impact on profitability. The Manufacturing Circle (2015) surveyed its members about mitigation strategies against electricity shortages: 63 per cent of those surveyed had their own generation (likely fuel generators), 53 per cent rescheduled production, 19 per cent reduced production, and 15 per cent either closed down production lines or substituted imports for local manufacture. Furthermore, 33 per cent of firms upgraded their existing capacity for greater energy and water efficiency.
} 
Looking from a firm-level perspective, Montmasson-Clair and Ryan (2014) explored the impact of electricity price increases on the competitiveness of mining industries, and the role these increases have played in renewable energy and energy investments in mining value chains. The study used annual financial statements and company interviews, and found surface mining, coal, and platinum group metal firms to have been marginally affected by electricity price increases, whilst gold miners were strongly affected. Deloitte (2011) found the electricity and non-ferrous metals sectors to be particularly vulnerable to electricity prices. Overall, the analysis by Montmasson-Clair and Ryan concluded that the effect of electricity price increases has not been sufficient to change firm behaviour and processes substantially, although some firms were reported to have already explored options around energy-efficient technologies, co-generation, and renewables.

Cameron and Rossouw (2012), in a study commissioned by Eskom, looked directly at the issue of tipping points by using key industrial customer information about electricity consumption and operating expenditure (obtained through Eskom-run surveys) to model the shutdown point of these firms. Cameron and Rossouw found that customers in 13 sectors-particularly in 'manufacturing of basic and fabricated metals' and 'manufacturing of coke, refined petroleum products, nuclear, chemicals, rubber, plastic'-had the potential to reach the tipping point. These customers account for about 25 per cent of Eskom's revenue. Further, six customers-accounting for 4.1 per cent of Eskom's revenue-were identified as 'in jeopardy' based on their tipping-point analysis.

There have been numerous studies on the economic impact of supply shortages and load-shedding in South Africa. Studies on the economic impact of price increases have been less common.

This paper attempts to build on the research that has already been done on elasticity of demand and tipping points by updating older research with newer, higher electricity prices, and looks at the impacts on individual firm profitability. Not only have electricity prices continued to increase since Cameron and Rossouw conducted their research in 2012, but commodity prices have also come under pressure. An additional contribution is that this paper extends the tipping-point analysis to the potential for own-generation in various electricity scenarios in the midst of falling levelized costs of own-generation.

\section{Impacts of electricity tariffs on operating profits and firm-level decisions}

\subsection{Method}

This section of the paper uses financial and sustainability information from the publicly available annual reports of 21 companies across different sectors (12 energy-intensive firms ${ }^{4}$ and nine less energy-intensive firms $\left.{ }^{5}\right)$. Nominal data for the last four available years of the annual financial statements of companies is extrapolated until 2040-41, using various assumptions around variables such as revenue growth, increases in costs, and tax-to-operating-profit ratios. The electricity costs of these companies are determined using annual electricity consumption data taken from firm sustainability reports. Where not available in the companies' annual reports, electricity cost information has been taken from existing literature or obtained from the companies directly.

\footnotetext{
${ }^{4}$ Sibanye, Harmony Gold, AngloPlat, Lonmin, Implats, Kumba Iron Ore, Evraz Highveld Steel, ArcelorMittal, Hulamin, PPC, AECI, and Transnet.

${ }^{5}$ Astral Foods, Clover, Pioneer Foods, Distell, Nampak, Nedbank, Telkom, Tsogo Sun, and Netcare.
} 
Electricity price data is sourced from Eskom as well as municipal benchmark data from the National Energy Regulator of South Africa. Electricity price increases are forecast until 2040-41 using three tariff scenarios: a base/low-tariff scenario, a high-tariff scenario, and a moderate-tariff scenario. In the outer years, it is assumed that electricity prices rise by an assumed consumer price inflation rate. As municipalities are allowed by the regulator to charge a surcharge on top of their Eskom rate, the municipal tariff increase differential is assumed to be one percentage point, for the sake of simplicity.

Table 1: Eskom tariff scenarios

\begin{tabular}{|c|c|c|c|c|c|c|c|c|c|c|c|}
\hline & $2015 / 16$ & $2016 / 17$ & $2017 / 18$ & $2018 / 19$ & $2019 / 20$ & $2020 / 21$ & $2021 / 22$ & $2022 / 23$ & $2023 / 24$ & $2024 / 25$ & $2025 / 26$ \\
\hline Base (low) & $12.7 \%$ & $8.0 \%$ & $8.0 \%$ & $8.0 \%$ & $5.8 \%$ & $5.8 \%$ & $5.8 \%$ & $5.8 \%$ & $5.8 \%$ & $5.8 \%$ & $5.8 \%$ \\
\hline High & $12.7 \%$ & $25.0 \%$ & $25.0 \%$ & $20.0 \%$ & $8.0 \%$ & $8.0 \%$ & $8.0 \%$ & $5.8 \%$ & $5.8 \%$ & $5.8 \%$ & $5.8 \%$ \\
\hline Moderate & $12.7 \%$ & $15.0 \%$ & $15.0 \%$ & $15.0 \%$ & $10.0 \%$ & $8.0 \%$ & $8.0 \%$ & $5.8 \%$ & $5.8 \%$ & $5.8 \%$ & $5.8 \%$ \\
\hline
\end{tabular}

Source: authors' calculations.

Table 2: Municipal tariff scenarios

\begin{tabular}{|c|c|c|c|c|c|c|c|c|c|c|c|}
\hline & $2015 / 16$ & $2016 / 17$ & $2017 / 18$ & $2018 / 19$ & $2019 / 20$ & $2020 / 21$ & $2021 / 22$ & $2022 / 23$ & $2023 / 24$ & $2024 / 25$ & $2025 / 26$ \\
\hline Base (low) & $13.7 \%$ & $9.0 \%$ & $9.0 \%$ & $9.0 \%$ & $6.8 \%$ & $6.8 \%$ & $6.8 \%$ & $6.8 \%$ & $6.8 \%$ & $6.8 \%$ & $6.8 \%$ \\
\hline High & $13.7 \%$ & $26.0 \%$ & $26.0 \%$ & $21.0 \%$ & $9.0 \%$ & $9.0 \%$ & $9.0 \%$ & $6.8 \%$ & $6.8 \%$ & $6.8 \%$ & $6.8 \%$ \\
\hline Moderate & $13.7 \%$ & $16.0 \%$ & $16.0 \%$ & $16.0 \%$ & $11.0 \%$ & $9.0 \%$ & $9.0 \%$ & $6.8 \%$ & $6.8 \%$ & $6.8 \%$ & $6.8 \%$ \\
\hline
\end{tabular}

Source: authors' calculations.

Individual firm electricity costs are linked to the tariff scenarios above. It is assumed that the 12 energy-intensive electricity users are supplied directly from Eskom, and that the less energyintensive firms are municipal customers. In order to determine the impacts of electricity price increases on the firms in the analysis, the net present value (NPV) of the operating profits from 2015-16 until 2040-41 are calculated for each firm. For comparison purposes, the NPV of the base scenario (the best case from a business perspective) for each firm is compared with the highand moderate-increase scenarios to see the size of the loss in NPV due to higher electricity tariffs.

\subsection{Results}

When we evaluate the energy-intensive firms in the study, there is no clear shutdown point in the base, high- or moderate-tariff scenarios. In other words, there is no point where the NPVs of firms' operating profits becomes marginal or negative. However, there is a significant loss in the NPVs of the operating profits of energy-intensive users between 2015-16 and 2040-41 when we compare the base scenario with high and moderate electricity price increases, as Figure 2 indicates. In the high-tariff scenario, declines in the NPVs of the operating profits of energy-intensive firms are between 0.4 per cent and 17.1 per cent, whilst in the moderate scenario the declines are between 0.2 and 8.5 per cent. As expected, the largest declines in operating profit NPVs can be seen in firms with the highest energy intensities. The biggest declines are seen in Evraz Highveld Steel (17.1 per cent), Implats (14.1 per cent), and PPC (12.4 per cent) in the high-tariff scenario. Kumba Iron Ore and AECI (a chemicals manufacturer) are the least affected energy-intensive users, due to their relatively low electricity intensities and costs.

Regarding the less energy-intensive users, the picture is rather similar: these firms do not reach a shutdown point in any scenario, but they do have lower operating profit NPVs in the high and moderate scenarios in comparison with the base scenario. However, the magnitude of the decline in NPV is much smaller than in the case of energy-intensive users (Figure 3). 
Figure 2: The impact of high- and moderate-tariff scenarios on operating profits in comparison with the base scenario-energy-intensive users

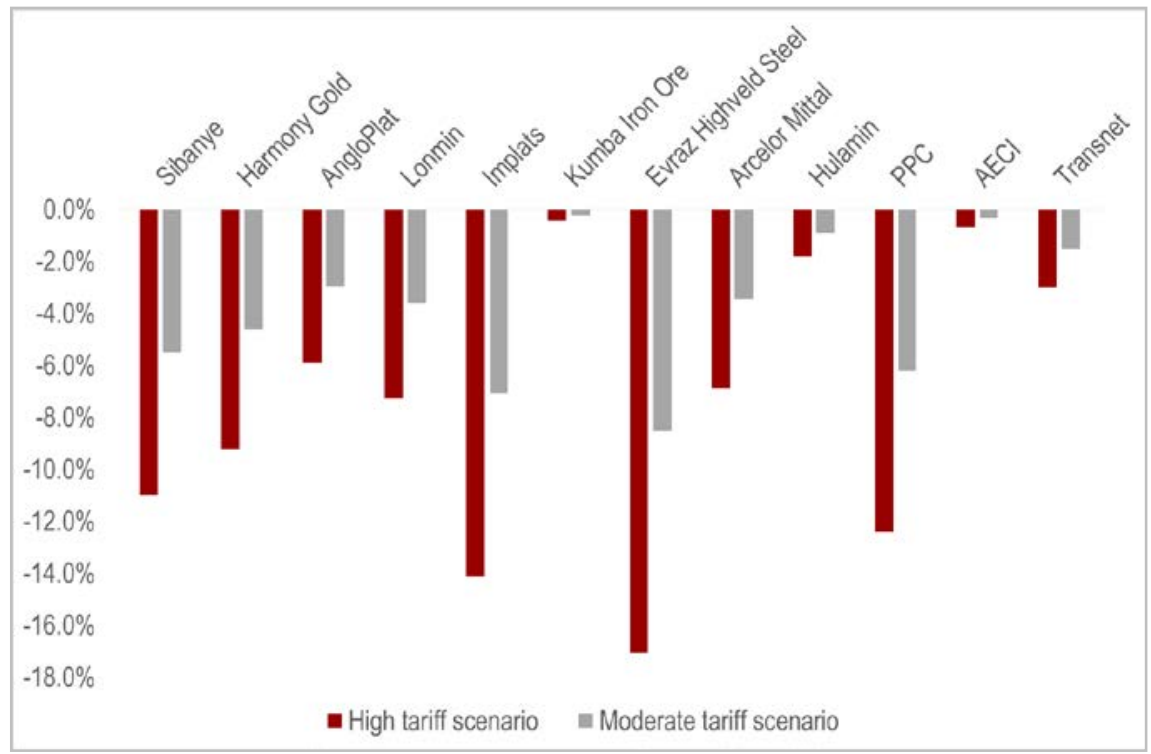

Source: authors' calculations.

Figure 3: The impact of high- and moderate-tariff scenarios on operating profits in comparison with the base scenario-other users

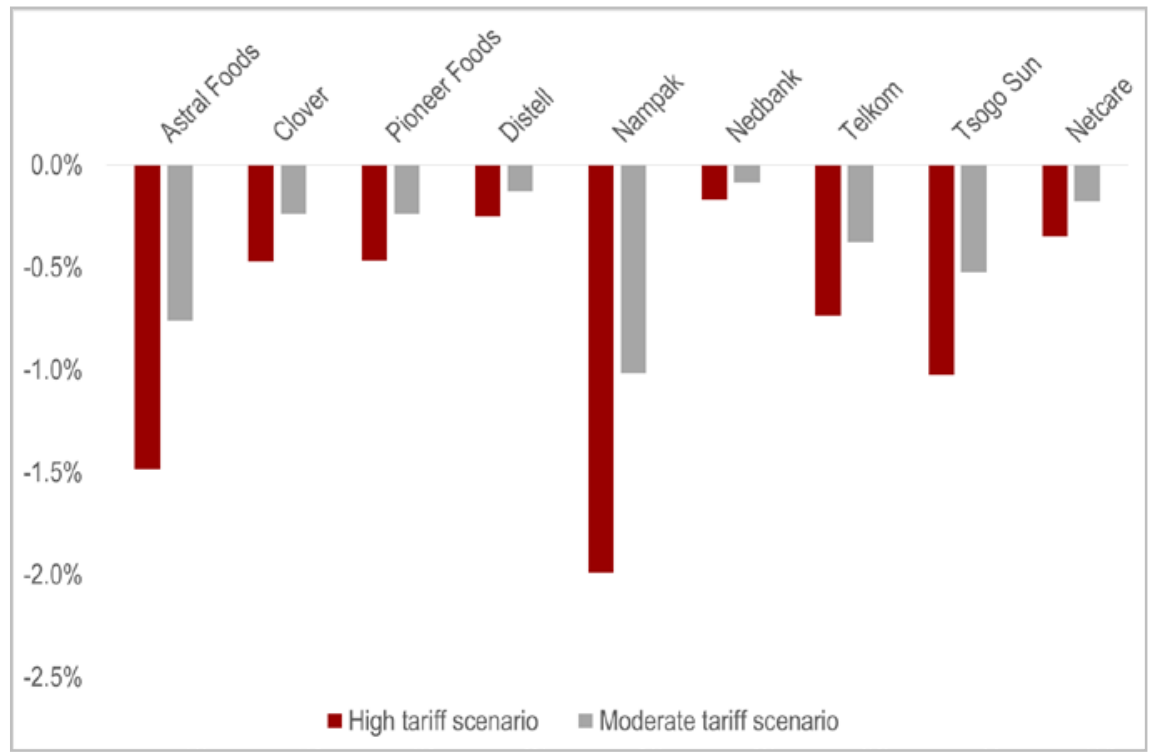

Source: authors' calculations.

In the high-tariff scenario, declines in the NPVs of operating profits are between 0.2 per cent and two per cent, whilst in the moderate scenario the declines are between 0.1 per cent and one per cent, in comparison with the base scenario. Nampak, Astral Foods, and the Tsogo Sun hotel group are the most affected in this group.

The analysis of the impact of tariff increases on operating profits indicates that while firms may not reach shutdown point, there is a material impact on the future operating profits of several firms. This in turn will likely have an impact on decisions to invest, depending on shareholders' willingness to tolerate lower returns. 
The levelized costs of alternative technologies have been declining dramatically over the past few years, and are expected to continue falling until at least 2020 (Table 3)_although more recently there are indications that the costs of renewable generation will fall further (International Renewable Energy Agency 2016).

Table 3: Anticipated changes in the levelized cost of electricity for various generation technologies

\begin{tabular}{|lccr|}
\hline R/kWh & 2012 & 2020 & \multicolumn{2}{r|}{ \% change } \\
\hline Concentrating solar power & 2.40 & 1.71 & $-29 \%$ \\
Coal & 0.80 & 1.69 & $111 \%$ \\
Open cycle gas turbines & 6.93 & 1.63 & $-76 \%$ \\
Wind & 0.86 & 0.76 & $-12 \%$ \\
Photovoltaics & 1.79 & 1.05 & $-41 \%$ \\
\hline
\end{tabular}

Source: SAPVIA (2013), reproduced here with permission.

The likelihood of firms investing in own-generation depends on several factors, such as electricity intensity, scope for energy efficiency gains, ability to pass costs on, and cost of own-generation relative to direct electricity costs. The general investment climate is an additional consideration for firms looking to invest in own-generation, particularly for long-term investments such as coal or closed-cycle gas turbines (CCGTs). It may be difficult for a firm to invest in a 20-year project, given that South Africa's investor and business confidence remains weak. Also, shareholders may not have the appetite to spend a significant amount of money investing in a non-core asset. However, Cloete et al. (2011) found that, although rising electricity tariffs were a major concern, sustainability of electricity supply was the most important factor for companies seeking to move towards own-generation technologies.

\subsection{Method}

This component of the study weighs the costs of investing in own-generation (including capital expenditure, operating expenditure, and financing costs) against the avoided electricity costs (i.e. benefits) in the different tariff scenarios for each company. For each scenario, the NPV of the net benefits of each own-generation technology ${ }^{6}$ over its lifespan is determined for each firm. Then the internal rates of return (IRRs) are compared with an assumed market return of 12 per cent. In other words, if the IRRs of the net benefits of a particular technology are less than 12 per cent for a firm, the company could make a better return by continuing to rely on the national grid and investing elsewhere.

The capex and opex data for the various technologies was obtained from the Electric Power Research Institute's (2011) 'Power Generation Technology Data for the Integrated Resource Plan', and was adjusted from 2011-12 to 2020-21 by price forecasts from the South African Photovoltaic Industry Association. From 2021-22 onwards, it is assumed that the costs of these technologies rise by the inflation assumption. The avoided electricity costs are equivalent to the electricity costs calculated in the first component of the study (Section 3). It is assumed that firms start investing

\footnotetext{
${ }^{6}$ For energy-intensive users, the following technologies are evaluated: a large (750-megawatt) coal plant; a small (250megawatt) coal plant; a CCGT plant (711 megawatts); a 200-megawatt wind farm; a 50-megawatt wind farm; 10megawatt photovoltaic and concentrating solar technologies. For the less energy-intensive firms, the coal, gas, and large-capacity wind plants are excluded, and the net benefits of 50-megawatt wind farms, 20-megawatt wind farms, and 10-megawatt photovoltaic and concentrating solar technologies are determined.
} 
in 2015-16 and only start benefitting from avoided electricity costs once construction is complete. A critical assumption in the model is the location of generation plant with respect to the location of the firm's plants, branches, factories, head offices, depots, or mines. As all the statements used are group financial statements, they include sites of different types (and energy intensities) across a wide range of locations.

Some firms might have relatively concentrated sites of electricity use, whilst others will be spread out across South Africa. ${ }^{8}$ Building own-generation and supplying different sites will require the use of existing transmission and distribution infrastructure. All transmission infrastructure is owned by Eskom, and distribution infrastructure by both Eskom and municipalities. Wheeling charges, i.e. charges for the use of this transmission and distribution infrastructure, are not taken into account in the first set of models, but we attempt to account for them in the second. Again, there are assumptions that need to be made about where the generation plant is located and what proportion needs to be wheeled, as financial statements do not disaggregate the information to this level. It is assumed to be unviable to invest in particular generation plant (by source of energy and size) if the load factor or operating capacity required of that plant in order to meet a firm's electricity demand is less than 55 per cent. This assumes, therefore, that any generation plant investment made by a firm is done only for its own consumption (not for feeding back into the grid with feed-in tariffs, or for selling to another firm). The model includes various assumptions around load factors, ${ }^{9}$ maintenance and energy costs, financing costs, debt/equity ratios, build times, and so on.

\subsection{Results}

Table 4 summarizes the viability of various own-generation technologies across all three tariff scenarios. In the base, moderate-, and high-tariff scenarios, it is viable for three energy-intensive firms to build a large coal plant; a 100x two-megawatt wind plant is viable for between seven and 10 firms out of the energy-intensive users. In terms of the other firms, for whom coal, CCGTs and large wind plants are not viable, a 25x two-megawatt wind plant is viable for six firms in the base and moderate scenarios, and for eight firms in the high-tariff scenario.

Table 4: Number of firms for whom own-generation is viable in various tariff scenarios

\begin{tabular}{|c|c|c|c|c|c|c|c|c|}
\hline & $\begin{array}{c}\text { Large } \\
\text { coal (750 } \\
\text { MW) }\end{array}$ & $\begin{array}{c}\text { Small } \\
\text { coal (250 } \\
\mathrm{MW})\end{array}$ & $\begin{array}{c}\text { CCGT } \\
(711 \\
\text { MW) }\end{array}$ & $\begin{array}{l}\text { Wind } \\
(100 x \\
2 M W)\end{array}$ & $\begin{array}{l}\text { Wind (25 } \\
\times 2 \mathrm{MW} \text { ) }\end{array}$ & $\begin{array}{l}\text { Wind (10 } \\
\times 2 \mathrm{MW})\end{array}$ & $\begin{array}{l}\text { Solar PV } \\
(10 \mathrm{MW})\end{array}$ & $\begin{array}{l}\text { Concentr } \\
\text { ating } \\
\text { solar (10 } \\
\text { MW) }\end{array}$ \\
\hline \multicolumn{9}{|c|}{ Energy intensive firms (out of 12 firms) } \\
\hline Base & 3 & 5 & 4 & 7 & 4 & $\mathrm{n} / \mathrm{a}$ & 4 & 4 \\
\hline High & 3 & 6 & 4 & 10 & 8 & $\mathrm{n} / \mathrm{a}$ & 7 & 7 \\
\hline Moderate & 3 & 5 & 4 & 10 & 6 & $\mathrm{n} / \mathrm{a}$ & 5 & 6 \\
\hline \multicolumn{9}{|c|}{ Other firms (out of 9 firms) } \\
\hline Base & $\mathrm{n} / \mathrm{a}$ & $\mathrm{n} / \mathrm{a}$ & $\mathrm{n} / \mathrm{a}$ & $\mathrm{n} / \mathrm{a}$ & 6 & 5 & 5 & 5 \\
\hline High & $\mathrm{n} / \mathrm{a}$ & $\mathrm{n} / \mathrm{a}$ & $\mathrm{n} / \mathrm{a}$ & $\mathrm{n} / \mathrm{a}$ & 8 & 7 & 6 & 7 \\
\hline Moderate & $\mathrm{n} / \mathrm{a}$ & $\mathrm{n} / \mathrm{a}$ & $\mathrm{n} / \mathrm{a}$ & $\mathrm{n} / \mathrm{a}$ & 6 & 6 & 6 & 6 \\
\hline
\end{tabular}

Source: authors' calculations.

\footnotetext{
${ }^{7}$ If firms choose to invest later, own-generation becomes progressively more viable.

${ }^{8}$ Although these firms are international, we attempt to isolate South African operations and energy use.

${ }^{9}$ For example, the load factors for solar and wind are assumed at 25 per cent, although latest estimates by Knorr et al. (2016) show wind load factors exceed 30 per cent in many parts of the country.
} 


\subsection{Wheeling charges}

The above analysis of own-generation potential does not include wheeling charges. Wheeling charges are a significant cost component of private generation, according to SAPVIA (2013). Wheeling charges, which are regulated by the energy regulator, have been highlighted as a significant barrier to the growth of alternative generation, particularly smaller generators (Nkabinde 2015).

Figure 4: Average tariff structure

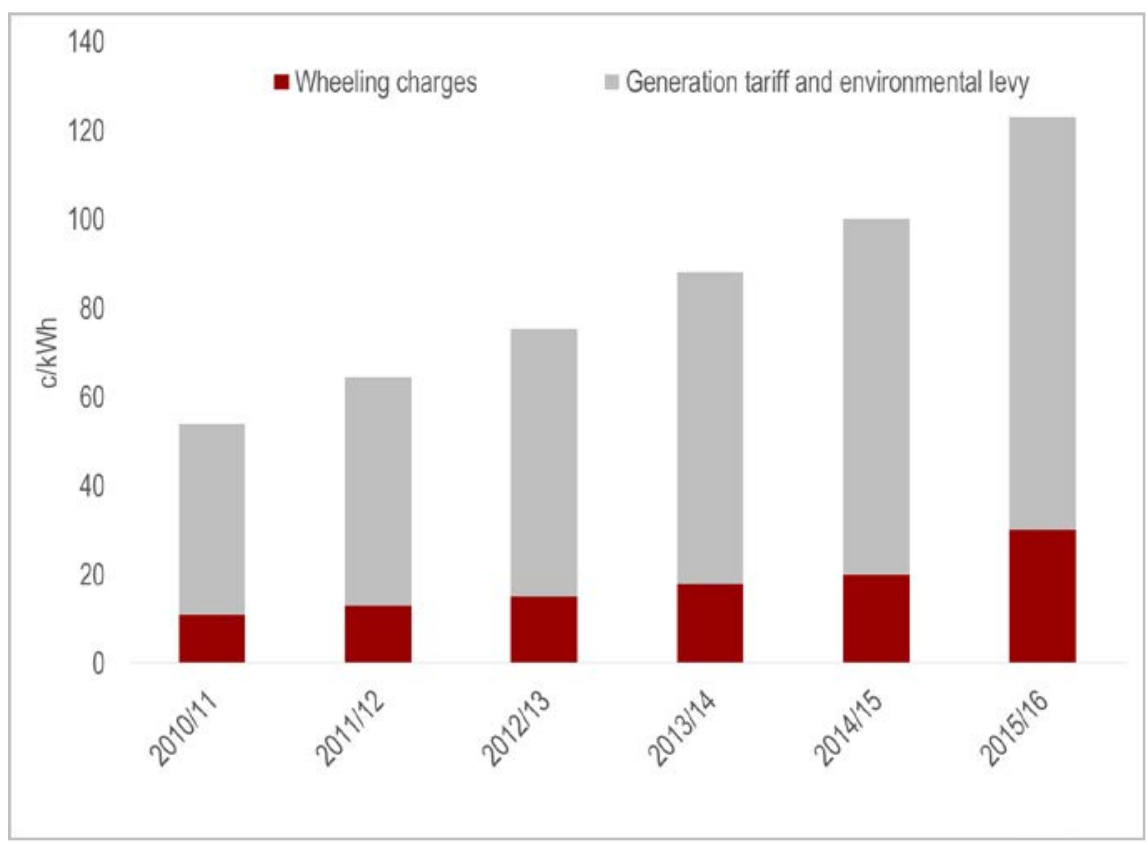

Source: SAPVIA (2013), reproduced here with permission.

Figure 5: Own-generation potential in various wheeling-charge and tariff scenarios

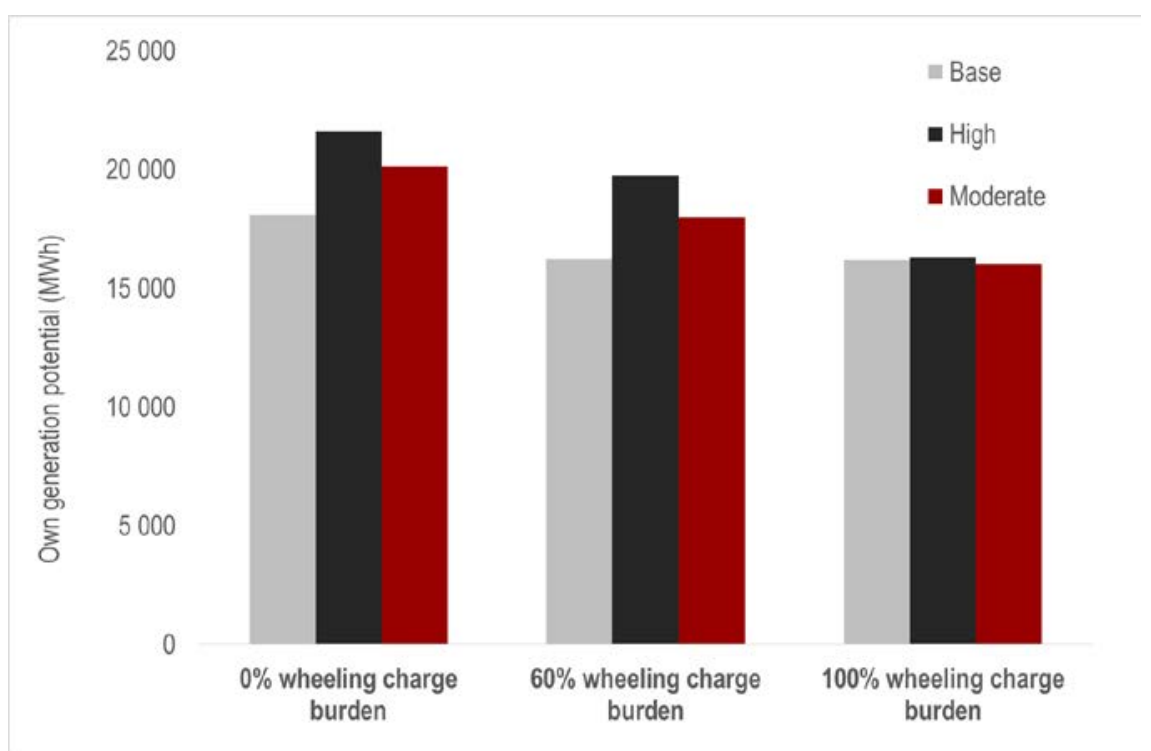

Source: authors' calculations. 
The own-generation component of the net benefit model was expanded to include a wheeling charge in the costs of own-generation projects, ${ }^{10}$ in order to determine the impacts of wheeling charges on the viability of these projects for firms. The impacts of three wheeling-charge burden scenarios (zero per cent, 60 per cent, and 100 per cent), ${ }^{11}$ assumed to apply to all firms in the study for simplification purposes, are compared with one another to see the impact on own-generation potential across the 21 firms in the study.

The potential size of own-generation is determined by selecting the technology with the highest generation capacity, with an IRR of 12 per cent or more, for each firm in each tariff scenario. As shown by the results in Figure 5, wheeling charges do make some own-generation projects unviable; however, the bulk of the projects (at least 16,000 megawatt-hours' worth) remain viable. This is likely due to the fact that this study only looks at large and generally profitable firms.

\subsection{Implications for Eskom}

Figure 6: Maximum own-generation potential in the moderate-tariff scenario compared with Eskom's sales by customer $^{12}$

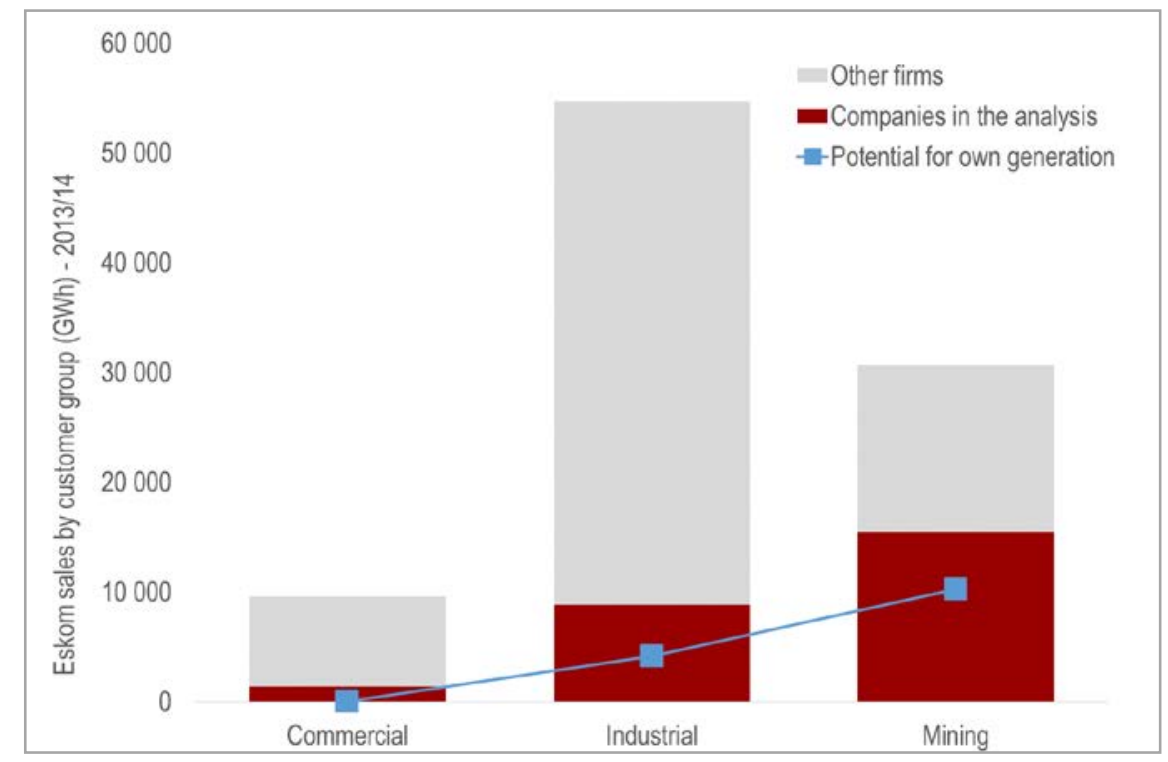

Source: authors' calculations.

Figure 6 depicts Eskom's total sales by customer group for industrial, commercial and mining customers. For example, Eskom sells 54,658 gigawatt-hours to industrial customers, and 30,667 gigawatt-hours to mining customers. The four commercial companies in this analysis account for 14 per cent of Eskom's commercial sales, the 10 industrial companies account for 16 per cent of Eskom's industrial sales, and the six mining firms in the study account for 51 per cent of mining sales. The estimated potential for own-generation among these customer groups-assuming grid access, a 60 per cent wheeling charge, and the moderate-tariff scenario-is equivalent to one per

\footnotetext{
10 These costs were taken from SAPVIA (2013) and extrapolated forward using the electricity tariff growth assumptions.

${ }^{11}$ The 60 per cent wheeling-charge scenario assumes that the own-generation plant is built at the location of the most energy-intensive plant of the firm, which consumes 40 per cent of the electricity produced, and that the remaining 60 per cent of the generation capacity is wheeled. The zero per cent and 100 per cent wheeling-charge scenarios are used in order to determine the range of wheeling costs.

${ }^{12}$ With a 60 per cent wheeling-charge burden in the moderate-tariff scenario.
} 
cent of Eskom's commercial sales, eight per cent of Eskom's industrial sales, and 34 per cent of Eskom's mining sales. This finding has significant implications for Eskom's sales and financial sustainability. As prices rise and alternative generation technologies become cheaper, Eskom could lose a portion of its customer base.

\section{$5 \quad$ Sensitivities and model limitations}

The models' results are not very sensitive to changes in energy efficiency, as the NPV impacts of improvements in energy efficiency to counter higher electricity tariffs are marginal over the entire 26-year period. But there is some sensitivity to changes in the revenue growth assumption. The operating profit model is not very sensitive to changes in the assumption of required rates of return, whilst the effects of changes to this assumption are different from firm to firm in the potential for own-generation model. However, many of the technologies have very high IRRs for some companies, far exceeding any reasonable assumption of rate of return.

The model assumes fixed and homogenous rates of growth in revenues and operating profits for the various companies, and does not model individual management decisions at firms, such as cutting costs or undertaking investments to increase revenues. The analysis also does not take into account firms' ability to pass costs on to consumers: it assumes that firms absorb all the costs of electricity price increases, and that these firms do not adjust to higher prices by cutting costs, making energy efficiency investments, etc., over the period of analysis. Further, it assumes away external influences such as cost escalations, changes to exchange rates, or sector-specific changes in demand or commodity price.

Second-round effects of the tariff increases (i.e. the knock-on impacts of electricity prices on other energy-intensive inputs) are also not included in the operating profit and own-generation models. The potential own-generation model does not take into account the appetite of shareholders to invest in a potentially costly project that is not core to their business, or the impact of the current investment climate on firms' willingness to invest in potentially long-term projects (such as a 30year coal plant). The cost of land is not included, and, critically, the own-generation model does not include the cost of unserved energy, which is likely to increase the net benefit of owngeneration significantly-particularly if firms are very dependent on stable and consistent electricity supply. Finally, this analysis only focuses on large firms and does not look at the impacts of rising tariffs on smaller firms, which is likely to be larger, particularly as many of them already face higher charges in the municipalities and face constraints on their decision-making or the options available to them.

\section{Concluding remarks}

Historically, the total impact of electricity price increases on gross value added in South Africa has not been severe, given the relatively small proportion of electricity as an input cost. However, demand for electricity has been becoming more elastic. The impact of rising electricity tariffs on firm operating profits, and the potential for own-generation, is explored in this paper. Although only two of the firms in this analysis are near a potential estimated shutdown point, the net present values of all firms and their future operating profits are eroded in the higher-tariff scenariossignificantly so for many of the energy-intensive users. This erosion in operating profits will likely have an impact on investment decisions. Firms may decide to cut costs, implement energy 
efficiency measures, close parts of their operations, move operations to neighbouring countries, invest in other sectors, or invest in their own generation capacity.

Investing in own-generation capacity is relatively viable, and some firms appear to have already reached a tipping point, even in a low-tariff scenario. Whilst this can have a positive outcome from a business sustainability and economic growth perspective, it can also impose costs on the economy more broadly and over the long term, as these smaller generation options are less efficient or do not benefit from economies of scale. In addition, it poses significant threats to the financial sustainability of Eskom and municipalities that rely heavily on energy-intensive users for revenue; this has been the experience of many other utilities around the world that have had to adjust to the changing business environment (O’Boyle 2017).

Own-generation decisions, whilst able to temporarily add electricity capacity in the short term, do not, however, affect overall electricity consumption and output over the longer period. When prices rise, some firms will choose to generate their own power, but others will simply look to reduce consumption and output, invest less in energy-intensive sectors, or shut down. With rising tariffs and falling costs of own-generation technologies, decisions taken by large energy-intensive firms in response to electricity tariff increases may lead to significant structural changes in the South African economy in the coming years. South Africa's integrated monopoly electricity provider will need to be prepared for a world where electricity consumers increasingly become prosumers (Sajn 2016).

\section{References}

Cameron, M., and R. Rossouw (2012). 'Modelling the Impact of Electricity Tariff Increases on Eskom's Top Customer Segment'. Available at: www.nersa.org.za/SAERC/Documents/ SAERC/Martin\%20Cameron\%20and\%20Riaan\%20Rossouw.pdf (accessed 3 December 2015).

Cloete, B., S. Chisadza, Y. Ramkolowan, B. Cohen, K. Mason-Jones, and C. Ras (2011). 'Ability of Firms to Adjust to Higher Energy Costs'. Report prepared for the National Treasury. Available at: www.dnaeconomics.com/assets/Usematthew/Ability_of_firms_to_adjust_to_higher_energ y_costs_Non-conf_Executive_Summary_Website_-_Feb_2012.pdf (accessed 19 February 2018).

Deloitte. (2009). 'Estimating the Elasticity of Electricity Prices in South Africa'. Johannesburg: Deloitte.

Deloitte (2011). 'The Economic Impact of Electricity Price Increases on Various Sectors of the South African Economy'. Johannesburg: Deloitte. Available at: www.eskom.co.za/ CustomerCare/MYPD3/Documents/Economic_Impact_of_Electrcity_Price_Increases_D ocument1.pdf (accessed 16 February 2018).

Edwards, T. (2012). 'China’s Power Sector Restructuring and Electricity Price Reforms'. Asia Paper, 6(2): 11.

Electric Power Research Institute (2012). 'Power Generation Technology Data for Integrated Resource Plan of South Africa'. Palo Alto: Electric Power Research Institute.

Eskom (n.d.a) 'Tariff History'. Available at: http://www.eskom.co.za/CustomerCare/ TariffsAndCharges/Pages/Tariff_History.aspx (accessed 23 February 2018). 
Eskom (n.d.b). 'Understanding Electricity'. Available at: www.eskom.co.za/AboutElectricity/ Electricity'Technologies/Pages/Understanding_Electricity.aspx (accessed 19 February 2018).

Eskom (2017). 'Integrated Results 2017'. Available at: www.eskom.co.za/IR2017/Pages/ default.aspx (accessed 19 February 2018).

Fisher-Vanden, K., E. Mansur, and Q. Wang (2013). 'Costly Blackouts? Measuring Productivity and Environmental Effects of Electricity Shortages'. NBER Working Paper 17741. Cambridge, MA: NBER.

Inglesi, R., and A. Pouris (2010). 'Forecasting Electricity Demand in South Africa: A Critique of Eskom's Projections'. South African Journal of Science, 106(1-2): 1-4.

Inglesi-Lotz, R., and J. Blignaut, (2011). 'Estimating the Price Elasticity of Demand for Electricity by Sector in South Africa'. South African Journal of Economic and Management Science, 14(4): 44965.

International Renewable Energy Agency (2016). 'The Power to Change: Solar and Wind Cost Reduction Potential to 2025'. Available at: www.irena.org/DocumentDownloads/ Publications/IRENA_Power_to_Change_2016.pdf (accessed 23 February 2018).

Kohler, M. (2013). 'Differential Electricity Pricing and Energy Efficiency in South Africa'. Working Paper 396. Cape Town: ERSA.

Knorr, K., B. Zimmermann, S. Bofinger, A. Fraunhofer, T. Bischof-Niemz, and C. Mushwana (2016). 'Wind and Solar PV Resource Aggregation Study for South Africa'. Pretoria: CSIR. Available at: www.csir.co.za/study-shows-abundance-wind-and-solar-resources-south-africa (accessed 23 February 2018).

Manufacturing Circle (2015). 'Manufacturing Bulletin Quarterly Review, Second Quarter 2015'. Available at: www.plasticsinfo.co.za/wp-content/uploads/2015/08/Manufacturing-CircleBulletin-Sept-2015.pdf (accessed 19 February 2018).

Montmasson-Clair, G., and G. Ryan (2014). 'The Impact of Electricity Price Increases on Selected Mining Sector and Smelting Value Chains in South Africa'. Pretoria: TIPS. Available at: www.tips.org.za/research-archive/sustainable-growth/green-economy-3/item/2905-theimpact-of-electricity-price-increases-on-the-competitiveness-of-selected-mining-sector-andsmelting-value-chains-in-south-africa (accessed 19 February 2018).

Nkabinde, S. (2015). 'Wheeling the Power'. Moneyweb, 24 July. Available at: www.moneyweb.co.za/ in-depth/moneyweb-business-insights/wheeling-the-power/ (accessed 19 February 2018).

O’Boyle, M. (2017). 'Three Ways Electric Utilities Can Avoid A Death Spiral'. Forbes, 25 September. Available at: www.forbes.com/sites/energyinnovation/2017/09/25/three-wayselectric-utilities-can-avoid-a-death-spiral/2/\#2f46d49713ea (accessed 19 February 2018).

Sajn, N. (2016). 'Electricity "Prosumers"”. Brussels: European Parliamentary Research Service. Available at: www.europarl.europa.eu/thinktank/en/document.html?reference=EPRS_BRI(2016)59351 8 (accessed 19 February 2018).

SAPVIA (2013). 'Overview of Solar PV in South Africa'. Cape Town: SAPVIA. Available at: www.sapvia.co.za/wp-content/uploads/2013/05/African-Utility-Week-Presentation-May2013.pdf (accessed 15 June 2016).

StatsSA (n.d.). 'Consumer Price Index, 1987-2016'. Available at: www.statssa.gov.za/ (accessed 23 February 2018). 
Appendix: additional tables

Table A1: Impact on operating profits—base versus high- and moderate-tariff scenarios

\begin{tabular}{|c|c|c|c|c|c|c|c|c|}
\hline Company & $\begin{array}{r}\text { Electricity } \\
\text { intensity }\end{array}$ & $\begin{array}{r}\text { Base } \\
\text { Scenario* } \\
\text { NPV @12\% } \\
\text { (Rmillions) }\end{array}$ & $\begin{array}{r}\text { High } \\
\text { Scenario } \\
\text { NPV } \\
\text { @12\% (R } \\
\text { millions) }\end{array}$ & $\begin{array}{r}\text { Difference } \\
\text { between } \\
\text { se and high } \\
\text { scenario } \\
\text { (Rmillions) }\end{array}$ & $\begin{array}{r}\% \\
\text { difference }\end{array}$ & $\begin{array}{r}\text { Moderate } \\
\text { Scenario } \\
\text { NPV } \\
@ 12 \% \text { (R } \\
\text { millions) } \\
\end{array}$ & $\begin{array}{r}\text { Difference } \\
\text { between } \\
\text { base and } \\
\text { moderate } \\
\text { scenario } \\
\text { (Rmillions) }\end{array}$ & $\begin{array}{r}\% \\
\text { difference }\end{array}$ \\
\hline \multicolumn{9}{|c|}{ ELECTRICITY INTENSIVE FIRMS } \\
\hline Sibanye & $20.0 \%$ & 107120 & 95357 & -11763 & $-11.0 \%$ & 101238 & -5882 & $-5.5 \%$ \\
\hline Harmony Gold & $15.0 \%$ & 83597 & 75897 & -7700 & $-9.2 \%$ & 79747 & -3851 & $-4.6 \%$ \\
\hline AngloPlat & $11.0 \%$ & 211746 & 199221 & -12525 & $-5.9 \%$ & 205483 & -6263 & $-3.0 \%$ \\
\hline Lonmin & $7.2 \%$ & 39560 & 36687 & -2872 & $-7.3 \%$ & 38123 & -1436 & $-3.6 \%$ \\
\hline Implats & $12.0 \%$ & 45529 & 39101 & -6428 & $-14.1 \%$ & 42315 & -3215 & $-7.1 \%$ \\
\hline Kumba Iron Ore & $3.4 \%$ & 321465 & 320093 & -1372 & $-0.4 \%$ & 320779 & -686 & $-0.2 \%$ \\
\hline Evraz Highveld Steel & $15.9 \%$ & 18767 & 15567 & -3200 & $-17.1 \%$ & 17167 & -1600 & $-8.5 \%$ \\
\hline Arcelor Mittal & $10.1 \%$ & 114379 & 106508 & -7871 & $-6.9 \%$ & 110443 & -3936 & $-3.4 \%$ \\
\hline Hulamin & $20.0 \%$ & 34831 & 34192 & -639 & $-1.8 \%$ & 34511 & -320 & $-0.9 \%$ \\
\hline PPC & $10.0 \%$ & 38918 & 34088 & -4830 & $-12.4 \%$ & 36503 & -2415 & $-6.2 \%$ \\
\hline $\mathrm{AECl}$ & $10.0 \%$ & 70570 & 70082 & -487 & $-0.7 \%$ & 70326 & -244 & $-0.3 \%$ \\
\hline Transnet & $11.2 \%$ & 387468 & 375857 & -11611 & $-3.0 \%$ & 381662 & -5807 & $-1.5 \%$ \\
\hline \multicolumn{9}{|l|}{ OTHER FIRMS } \\
\hline Astral Foods & $2.5 \%$ & 91583 & 90224 & -1359 & $-1.5 \%$ & 90889 & -695 & $-0.8 \%$ \\
\hline Clover & $2.3 \%$ & 92601 & 92166 & -435 & $-0.5 \%$ & 92379 & -222 & $-0.2 \%$ \\
\hline Pioneer Foods & $2.0 \%$ & 275523 & 274234 & -1289 & $-0.5 \%$ & 274864 & -659 & $-0.2 \%$ \\
\hline Distell & $2.3 \%$ & 157727 & 157326 & -401 & $-0.3 \%$ & 157522 & -205 & $-0.1 \%$ \\
\hline Nampak & $6.0 \%$ & 124011 & 121544 & -2467 & $-2.0 \%$ & 122750 & -1261 & $-1.0 \%$ \\
\hline Nedbank & $0.8 \%$ & 474575 & 473775 & -801 & $-0.2 \%$ & 474166 & -409 & $-0.1 \%$ \\
\hline Telkom & $0.8 \%$ & 428541 & 425393 & -3149 & $-0.7 \%$ & 426932 & -1609 & $-0.4 \%$ \\
\hline Tsogo Sun & $2.0 \%$ & 120561 & 119326 & -1235 & $-1.0 \%$ & 119930 & -631 & $-0.5 \%$ \\
\hline Netcare & $2.0 \%$ & 429053 & 427553 & -1500 & $-0.3 \%$ & 428286 & -767 & $-0.2 \%$ \\
\hline
\end{tabular}

Source: authors' calculations. 
Tables A2-A22: Rates of return of net benefits of various own-generation technology options, without wheeling charges (in comparison with assumed market IRR of 12 per cent)

Table A2

\begin{tabular}{|c|c|c|c|c|c|c|}
\hline \multicolumn{7}{|l|}{ Sibanye } \\
\hline 2014/15 electricity consumption (MWh) & 4274290 & & & & & \\
\hline Energy intensity & $20 \%$ & & & & & \\
\hline Technology & $\begin{array}{l}\text { Capacity of } \\
\text { plant }\end{array}$ & $\begin{array}{l}\text { MWH } \\
\text { produced p.a }\end{array}$ & $\begin{array}{l}\text { \% of total } \\
\text { demand }\end{array}$ & Base case IRR & $\begin{array}{l}\text { High } \\
\text { scenario IRR }\end{array}$ & $\begin{array}{l}\text { Moderate } \\
\text { scenario IRR }\end{array}$ \\
\hline Large coal & $66.0 \%$ & 3976295 & $93.0 \%$ & $11 \%$ & $20 \%$ & $16 \%$ \\
\hline Small coal & $85.0 \%$ & 1682796 & $39.4 \%$ & $16 \%$ & $30 \%$ & $24 \%$ \\
\hline CCGT & $71.0 \%$ & 3926856 & $91.9 \%$ & $79 \%$ & $111 \%$ & $95 \%$ \\
\hline Wind $(100 \times 2 \mathrm{MW})$ & $15.0 \%$ & 250974 & $5.9 \%$ & $10 \%$ & $22 \%$ & $17 \%$ \\
\hline Wind $(25 \times 2 \mathrm{MW})$ & $15.0 \%$ & 62744 & $1.5 \%$ & $4 \%$ & $15 \%$ & $10 \%$ \\
\hline Solar PV & $26.0 \%$ & 22320 & $0.5 \%$ & $3 \%$ & $12 \%$ & $8 \%$ \\
\hline Concentrating solar & $26.0 \%$ & 21637 & $0.5 \%$ & $5 \%$ & $14 \%$ & $9 \%$ \\
\hline
\end{tabular}

Source: authors' calculations.

Table A3

\begin{tabular}{|c|c|c|c|c|c|c|}
\hline \multicolumn{7}{|l|}{ Harmony Gold } \\
\hline 2014/15 electricity consumption (MWh) & 2798000 & & & & & \\
\hline Energy intensity & $15 \%$ & & & & & \\
\hline Technology & $\begin{array}{l}\text { Capacity of } \\
\text { plant }\end{array}$ & $\begin{array}{l}\text { MWH } \\
\text { produced p.a }\end{array}$ & $\begin{array}{l}\text { \% of total } \\
\text { demand }\end{array}$ & Base case IRR & $\begin{array}{l}\text { High } \\
\text { scenario IRR }\end{array}$ & $\begin{array}{l}\text { Moderate } \\
\text { scenario IRR }\end{array}$ \\
\hline Large coal & $45.0 \%$ & 2711111 & $96.9 \%$ & $0 \%$ & $9 \%$ & $5 \%$ \\
\hline Small coal & $85.0 \%$ & 1682796 & $60.1 \%$ & $8 \%$ & $24 \%$ & $17 \%$ \\
\hline CCGT & $49.0 \%$ & 2710084 & $96.9 \%$ & $44 \%$ & $76 \%$ & $61 \%$ \\
\hline Wind $(100 \times 2 \mathrm{MW})$ & $15.0 \%$ & 250974 & $9.0 \%$ & $4 \%$ & $17 \%$ & $11 \%$ \\
\hline Wind $(25 \times 2 M W)$ & $15.0 \%$ & 62744 & $2.2 \%$ & $-1 \%$ & $10 \%$ & $5 \%$ \\
\hline Solar PV & $26.0 \%$ & 22320 & $0.8 \%$ & $-1 \%$ & $8 \%$ & $4 \%$ \\
\hline Concentrating solar & $26.0 \%$ & 21637 & $0.8 \%$ & $0 \%$ & $10 \%$ & $5 \%$ \\
\hline
\end{tabular}

Source: authors' calculations. 
Table A4

\begin{tabular}{|c|c|c|c|c|c|c|}
\hline \multicolumn{7}{|l|}{ AngloPlat } \\
\hline 2014/15 electricity consumption (MWh) & 4551144 & & & & & \\
\hline \multirow{2}{*}{\begin{tabular}{|l} 
Energy intensity \\
Technology
\end{tabular}} & $11 \%$ & & & & & \\
\hline & $\begin{array}{l}\text { Capacity of } \\
\text { plant }\end{array}$ & $\begin{array}{l}\text { MWH } \\
\text { produced p.a }\end{array}$ & $\begin{array}{l}\text { \% of total } \\
\text { demand }\end{array}$ & Base case IRR & $\begin{array}{l}\text { High } \\
\text { scenario IRR }\end{array}$ & $\begin{array}{l}\text { Moderate } \\
\text { scenario IRR }\end{array}$ \\
\hline Large coal & $70.0 \%$ & 4217283 & $92.7 \%$ & $22 \%$ & $29 \%$ & $26 \%$ \\
\hline Small coal & $85.0 \%$ & 1682796 & $37.0 \%$ & $31 \%$ & $43 \%$ & $37 \%$ \\
\hline CCGT & $80.0 \%$ & 4424627 & $97.2 \%$ & $123 \%$ & $147 \%$ & $135 \%$ \\
\hline Wind $(100 \times 2 \mathrm{MW})$ & $15.0 \%$ & 250974 & $5.5 \%$ & $22 \%$ & $33 \%$ & $28 \%$ \\
\hline Wind $(25 \times 2 \mathrm{MW})$ & $15.0 \%$ & 62744 & $1.4 \%$ & $15 \%$ & $25 \%$ & $20 \%$ \\
\hline Solar PV & $26.0 \%$ & 22320 & $0.5 \%$ & $13 \%$ & $21 \%$ & $17 \%$ \\
\hline Concentrating solar & $26.0 \%$ & 21637 & $0.5 \%$ & $15 \%$ & $24 \%$ & $19 \%$ \\
\hline
\end{tabular}

Source: authors' calculations.

Table A5

\begin{tabular}{|c|c|c|c|c|c|c|}
\hline Lonmin & & & & & & \\
\hline 2014/15 electricity consumption (MWh) & 1043777 & & & & & \\
\hline Energy intensity & $7 \%$ & & & & & \\
\hline Technology & $\begin{array}{l}\text { Capacity of } \\
\text { plant }\end{array}$ & $\begin{array}{l}\text { MWH } \\
\text { produced p.a }\end{array}$ & $\begin{array}{l}\% \text { of total } \\
\text { demand }\end{array}$ & Base case IRR & $\begin{array}{l}\text { High } \\
\text { scenario IRR }\end{array}$ & $\begin{array}{l}\text { Moderate } \\
\text { scenario IRR }\end{array}$ \\
\hline Large coal & $16.0 \%$ & 963950 & $92.4 \%$ & \#NUM! & $-6 \%$ & $-10 \%$ \\
\hline Small coal & $52.0 \%$ & 1029475 & $98.6 \%$ & $1 \%$ & $13 \%$ & $8 \%$ \\
\hline CCGT & $19.0 \%$ & 1050849 & $100.7 \%$ & $17 \%$ & $36 \%$ & $27 \%$ \\
\hline Wind $(100 \times 2 \mathrm{MW})$ & $15.0 \%$ & 250974 & $24.0 \%$ & $6 \%$ & $18 \%$ & $13 \%$ \\
\hline Wind $(25 \times 2 M W)$ & $15.0 \%$ & 62744 & $6.0 \%$ & $0 \%$ & $12 \%$ & $7 \%$ \\
\hline Solar PV & $26.0 \%$ & 22320 & $2.1 \%$ & $0 \%$ & $\mathbf{9 \%}$ & $5 \%$ \\
\hline Concentrating solar & $26.0 \%$ & 21637 & $2.1 \%$ & $1 \%$ & $11 \%$ & $6 \%$ \\
\hline
\end{tabular}

Source: authors' calculations.

Table A6

\begin{tabular}{|c|c|c|c|c|c|c|}
\hline \multicolumn{7}{|l|}{ Implats } \\
\hline 2014/15 electricity consumption (MWh) & 2335790 & & & & & \\
\hline \multirow{2}{*}{\begin{tabular}{|l} 
Energy intensity \\
Technology
\end{tabular}} & \multicolumn{2}{|l|}{$12 \%$} & \multirow[b]{2}{*}{$\begin{array}{l}\text { \% of total } \\
\text { demand }\end{array}$} & \multirow[b]{2}{*}{ Base case IRR } & \multirow[b]{2}{*}{$\begin{array}{l}\text { High } \\
\text { scenario IRR }\end{array}$} & \multirow[b]{2}{*}{$\begin{array}{l}\text { Moderate } \\
\text { scenario IRR }\end{array}$} \\
\hline & $\begin{array}{l}\text { Capacity of } \\
\text { plant }\end{array}$ & $\begin{array}{l}\text { MWH } \\
\text { produced p.a }\end{array}$ & & & & \\
\hline Large coal & $40.0 \%$ & 2409876 & $103.2 \%$ & $3 \%$ & $11 \%$ & $8 \%$ \\
\hline Small coal & $85.0 \%$ & 1682796 & $72.0 \%$ & $17 \%$ & $31 \%$ & $25 \%$ \\
\hline CCGT & $40.0 \%$ & 2212313 & $94.7 \%$ & $53 \%$ & $78 \%$ & $66 \%$ \\
\hline Wind $(100 \times 2 \mathrm{MW})$ & $15.0 \%$ & 250974 & $10.7 \%$ & $11 \%$ & $23 \%$ & $17 \%$ \\
\hline Wind $(25 \times 2 \mathrm{MW})$ & $15.0 \%$ & 62744 & $2.7 \%$ & $5 \%$ & $16 \%$ & $11 \%$ \\
\hline Solar PV & $26.0 \%$ & 22320 & $1.0 \%$ & $4 \%$ & $12 \%$ & $8 \%$ \\
\hline Concentrating solar & $26.0 \%$ & 21637 & $0.9 \%$ & $5 \%$ & $14 \%$ & $10 \%$ \\
\hline
\end{tabular}

Source: authors' calculations. 
Table A7

\begin{tabular}{|c|c|c|c|c|c|c|}
\hline \multicolumn{7}{|l|}{ Kumba Iron Ore } \\
\hline 2014/15 electricity consumption (MWh) & 498600 & & & & & \\
\hline \multicolumn{7}{|l|}{ Energy intensity } \\
\hline Technology & $\begin{array}{l}\text { Capacity of } \\
\text { plant }\end{array}$ & $\begin{array}{l}\text { MWH } \\
\text { produced p.a }\end{array}$ & $\begin{array}{l}\text { \% of total } \\
\text { demand }\end{array}$ & Base case IRR & $\begin{array}{l}\text { High } \\
\text { scenario IRR }\end{array}$ & $\begin{array}{l}\text { Moderate } \\
\text { scenario IRR }\end{array}$ \\
\hline Large coal & $8.0 \%$ & 481975 & $96.7 \%$ & $-7 \%$ & $-4 \%$ & $-5 \%$ \\
\hline Small coal & $25.0 \%$ & 494940 & $99.3 \%$ & $11 \%$ & $16 \%$ & $14 \%$ \\
\hline CCGT & $8.0 \%$ & 442463 & $88.7 \%$ & $30 \%$ & $37 \%$ & $34 \%$ \\
\hline Wind $(100 \times 2 \mathrm{MW})$ & $15.0 \%$ & 250974 & $50.3 \%$ & $37 \%$ & $46 \%$ & $42 \%$ \\
\hline Wind $(25 \times 2 \mathrm{MW})$ & $15.0 \%$ & 62744 & $12.6 \%$ & $31 \%$ & $40 \%$ & $35 \%$ \\
\hline Solar PV & $26.0 \%$ & 22320 & $4.5 \%$ & $26 \%$ & $35 \%$ & $30 \%$ \\
\hline Concentrating solar & $26.0 \%$ & 21637 & $4.3 \%$ & $30 \%$ & $39 \%$ & $34 \%$ \\
\hline
\end{tabular}

Source: authors' calculations.

Table A8

\begin{tabular}{|c|c|c|c|c|c|c|}
\hline \multicolumn{7}{|l|}{ Evraz Highveld Steel } \\
\hline 2014/15 electricity consumption (MWh) & 1431000 & & & & & \\
\hline Energy intensity & $16 \%$ & & & & & \\
\hline Technology & $\begin{array}{l}\text { Capacity of } \\
\text { plant }\end{array}$ & $\begin{array}{l}\text { MWH } \\
\text { produced p.a }\end{array}$ & $\begin{array}{l}\text { \% of total } \\
\text { demand }\end{array}$ & Base case IRR & $\begin{array}{l}\text { High } \\
\text { scenario IRR }\end{array}$ & $\begin{array}{l}\text { Moderate } \\
\text { scenario IRR }\end{array}$ \\
\hline Large coal & $23.0 \%$ & 1385679 & $96.8 \%$ & $-14 \%$ & $-4 \%$ & $-8 \%$ \\
\hline Small coal & $70.0 \%$ & 1385832 & $96.8 \%$ & $0 \%$ & $14 \%$ & $8 \%$ \\
\hline CCGT & $25.0 \%$ & 1382696 & $96.6 \%$ & $15 \%$ & $36 \%$ & $26 \%$ \\
\hline Wind $(100 \times 2 M W)$ & $15.0 \%$ & 250974 & $17.5 \%$ & $0 \%$ & $12 \%$ & $7 \%$ \\
\hline Wind (25 x 2MW) & $15.0 \%$ & 62744 & $4.4 \%$ & $-5 \%$ & $6 \%$ & $2 \%$ \\
\hline Solar PV & $26.0 \%$ & 22320 & $1.6 \%$ & $-4 \%$ & $4 \%$ & $1 \%$ \\
\hline Concentrating solar & $26.0 \%$ & 21637 & $1.5 \%$ & $-3 \%$ & $6 \%$ & $2 \%$ \\
\hline
\end{tabular}

Source: authors' calculations.

Table A9

\begin{tabular}{|c|c|c|c|c|c|c|}
\hline \multicolumn{7}{|l|}{ Arcelor Mittal } \\
\hline 2014/15 electricity consumption (MWh) & 3520000 & & & & & \\
\hline Energy intensity & $10 \%$ & & & & & \\
\hline Technology & $\begin{array}{l}\text { Capacity of } \\
\text { plant }\end{array}$ & $\begin{array}{l}\text { MWH } \\
\text { produced p.a }\end{array}$ & $\begin{array}{l}\% \text { of total } \\
\text { demand }\end{array}$ & Base case IRR & $\begin{array}{l}\text { High } \\
\text { scenario IRR }\end{array}$ & $\begin{array}{l}\text { Moderate } \\
\text { scenario IRR }\end{array}$ \\
\hline Large coal & $58.0 \%$ & 3494320 & $99.3 \%$ & $12 \%$ & $19 \%$ & $16 \%$ \\
\hline Small coal & $85.0 \%$ & 1682796 & $47.8 \%$ & $22 \%$ & $33 \%$ & $28 \%$ \\
\hline CCGT & $62.0 \%$ & 3429086 & $97.4 \%$ & $86 \%$ & $108 \%$ & $97 \%$ \\
\hline Wind $(100 \times 2 \mathrm{MW})$ & $15.0 \%$ & 250974 & $7.1 \%$ & $15 \%$ & $24 \%$ & $20 \%$ \\
\hline Wind $(25 \times 2 \mathrm{MW})$ & $15.0 \%$ & 62744 & $1.8 \%$ & $9 \%$ & $17 \%$ & $13 \%$ \\
\hline Solar PV & $26.0 \%$ & 22320 & $0.6 \%$ & $7 \%$ & $14 \%$ & $10 \%$ \\
\hline Concentrating solar & $26.0 \%$ & 21637 & $0.6 \%$ & $9 \%$ & $16 \%$ & $12 \%$ \\
\hline
\end{tabular}

Source: authors' calculations. 
Table A10

\begin{tabular}{|c|c|c|c|c|c|c|}
\hline \multicolumn{7}{|l|}{ Hulamin } \\
\hline 2014/15 electricity consumption (MWh) & 285848 & & & & & \\
\hline Energy intensity & $20 \%$ & & & & & \\
\hline Technology & $\begin{array}{l}\text { Capacity of } \\
\text { plant }\end{array}$ & $\begin{array}{l}\text { MWH } \\
\text { produced p.a }\end{array}$ & $\begin{array}{l}\text { \% of total } \\
\text { demand }\end{array}$ & Base case IRR & $\begin{array}{l}\text { High } \\
\text { scenario IRR }\end{array}$ & $\begin{array}{l}\text { Moderate } \\
\text { scenario IRR }\end{array}$ \\
\hline Large coal & $4.0 \%$ & 240988 & $84.3 \%$ & $-3 \%$ & $-1 \%$ & $-2 \%$ \\
\hline Small coal & $13.0 \%$ & 257369 & $90.0 \%$ & $20 \%$ & $22 \%$ & $21 \%$ \\
\hline CCGT & $5.0 \%$ & 276539 & $96.7 \%$ & $51 \%$ & $54 \%$ & $52 \%$ \\
\hline Wind $(100 \times 2 M W)$ & $15.0 \%$ & 250974 & $87.8 \%$ & $84 \%$ & $87 \%$ & $86 \%$ \\
\hline Wind $(25 \times 2 \mathrm{MW})$ & $15.0 \%$ & 62744 & $21.9 \%$ & $91 \%$ & $96 \%$ & $93 \%$ \\
\hline Solar PV & $26.0 \%$ & 22320 & $7.8 \%$ & $94 \%$ & $100 \%$ & $97 \%$ \\
\hline Concentrating solar & $26.0 \%$ & 21637 & $7.6 \%$ & $104 \%$ & $110 \%$ & $107 \%$ \\
\hline
\end{tabular}

Source: authors' calculations.

Table A11

\begin{tabular}{|c|c|c|c|c|c|c|}
\hline \multicolumn{7}{|l|}{$\begin{array}{l}\text { PPC } \\
2014 / 15 \text { electricity consumption (MWh) }\end{array}$} \\
\hline Energy intensity & $10 \%$ & & & & & \\
\hline Technology & $\begin{array}{l}\text { Capacity of } \\
\text { plant }\end{array}$ & $\begin{array}{l}\text { MWH } \\
\text { produced p.a }\end{array}$ & $\begin{array}{l}\text { \% of total } \\
\text { demand }\end{array}$ & Base case IRR & $\begin{array}{l}\text { High } \\
\text { scenario IRR }\end{array}$ & $\begin{array}{l}\text { Moderate } \\
\text { scenario IRR }\end{array}$ \\
\hline Large coal & $32.0 \%$ & 1927901 & $89.3 \%$ & \#NUM! & $-8 \%$ & \#NUM! \\
\hline Small coal & $85.0 \%$ & 1682796 & $77.9 \%$ & \#NUM! & $4 \%$ & $-7 \%$ \\
\hline CCGT & $35.0 \%$ & 1935774 & $89.6 \%$ & \#NUM! & $24 \%$ & $8 \%$ \\
\hline Wind $(100 \times 2 M W)$ & $15.0 \%$ & 250974 & $11.6 \%$ & \#NUM! & $0 \%$ & $-9 \%$ \\
\hline Wind ( $25 \times 2 M W)$ & $15.0 \%$ & 62744 & $2.9 \%$ & \#NUM! & $-4 \%$ & $-13 \%$ \\
\hline Solar PV & $26.0 \%$ & 22320 & $1.0 \%$ & \#NUM! & $-4 \%$ & $-10 \%$ \\
\hline Concentrating solar & $26.0 \%$ & 21637 & $1.0 \%$ & \#NUM! & $-3 \%$ & $-8 \%$ \\
\hline
\end{tabular}

Source: authors' calculations.

Table A12

\begin{tabular}{|c|c|c|c|c|c|c|}
\hline \multicolumn{7}{|l|}{$\begin{array}{l}\text { AECI } \\
\text { 2014/15 electricity consumption (MWh) }\end{array}$} \\
\hline Technology & $\begin{array}{l}\text { Capacity of } \\
\text { plant }\end{array}$ & $\begin{array}{l}\text { MWH } \\
\text { produced p.a }\end{array}$ & $\begin{array}{l}\text { \% of total } \\
\text { demand }\end{array}$ & Base case IRR & $\begin{array}{l}\text { High } \\
\text { scenario IRR }\end{array}$ & $\begin{array}{l}\text { Moderate } \\
\text { scenario IRR }\end{array}$ \\
\hline Large coal & $3.0 \%$ & 180741 & $82.9 \%$ & $-2 \%$ & $-1 \%$ & $-1 \%$ \\
\hline Small coal & $11.0 \%$ & 217774 & $99.9 \%$ & $25 \%$ & $26 \%$ & $26 \%$ \\
\hline CCGT & $3.0 \%$ & 165924 & $76.1 \%$ & $44 \%$ & $46 \%$ & $45 \%$ \\
\hline Wind $(100 \times 2 \mathrm{MW})$ & $15.0 \%$ & 250974 & $115.1 \%$ & $104 \%$ & $106 \%$ & $105 \%$ \\
\hline Wind $(25 \times 2 M W)$ & $15.0 \%$ & 62744 & $28.8 \%$ & $121 \%$ & $125 \%$ & $123 \%$ \\
\hline Solar PV & $26.0 \%$ & 22320 & $10.2 \%$ & $138 \%$ & $144 \%$ & $141 \%$ \\
\hline Concentrating solar & $26.0 \%$ & 21637 & $9.9 \%$ & $151 \%$ & $157 \%$ & $153 \%$ \\
\hline
\end{tabular}

Source: authors' calculations. 
Table A13

\begin{tabular}{|c|c|c|c|c|c|c|}
\hline \multicolumn{7}{|l|}{ Transnet } \\
\hline 2014/15 electricity consumption (MWh) & 3554822 & & & & & \\
\hline Energy intensity & $11 \%$ & & & & & \\
\hline Technology & $\begin{array}{l}\text { Capacity of } \\
\text { plant }\end{array}$ & $\begin{array}{l}\text { MWH } \\
\text { produced p.a }\end{array}$ & $\begin{array}{l}\text { \% of total } \\
\text { demand }\end{array}$ & Base case IRR & $\begin{array}{l}\text { High } \\
\text { scenario IRR }\end{array}$ & $\begin{array}{l}\text { Moderate } \\
\text { scenario IRR }\end{array}$ \\
\hline Large coal & $57.0 \%$ & 3434073 & $96.6 \%$ & $13 \%$ & $22 \%$ & $18 \%$ \\
\hline Small coal & $85.0 \%$ & 1682796 & $47.3 \%$ & $24 \%$ & $39 \%$ & $32 \%$ \\
\hline CCGT & $63.0 \%$ & 3484394 & $98.0 \%$ & $91 \%$ & $121 \%$ & $106 \%$ \\
\hline Wind $(100 \times 2 M W)$ & $15.0 \%$ & 250974 & $7.1 \%$ & $16 \%$ & $29 \%$ & $23 \%$ \\
\hline Wind $(25 \times 2 \mathrm{MW})$ & $15.0 \%$ & 62744 & $1.8 \%$ & $10 \%$ & $22 \%$ & $16 \%$ \\
\hline Solar PV & $26.0 \%$ & 22320 & $0.6 \%$ & $8 \%$ & $18 \%$ & $13 \%$ \\
\hline Concentrating solar & $26.0 \%$ & 21637 & $0.6 \%$ & $10 \%$ & $20 \%$ & $15 \%$ \\
\hline
\end{tabular}

Source: authors' calculations.

Table A14

\begin{tabular}{|c|c|c|c|c|c|c|c|}
\hline Astral Foods & & & & & & & \\
\hline 2014/15 electricity consumption (MWh) & 280560 & & & & & & \\
\hline Energy intensity & $3 \%$ & & & & & & \\
\hline Technology & $\begin{array}{l}\text { Capacity of } \\
\text { plant }\end{array}$ & $\begin{array}{l}\text { MWH } \\
\text { produced p.a }\end{array}$ & $\begin{array}{l}\% \text { of total } \\
\text { demand }\end{array}$ & Base case IRR & & $\begin{array}{l}\text { High } \\
\text { scenario IRR }\end{array}$ & $\begin{array}{l}\text { Moderate } \\
\text { scenario IRR }\end{array}$ \\
\hline Wind $(10 \times 2 \mathrm{MW})$ & $15.0 \%$ & 25097 & $8.9 \%$ & & $4 \%$ & $14 \%$ & $10 \%$ \\
\hline Wind $(25 \times 2 M W)$ & $15.0 \%$ & 62744 & $22.4 \%$ & & $1 \%$ & $11 \%$ & $7 \%$ \\
\hline Solar PV & $26.0 \%$ & 22320 & $8.0 \%$ & & $3 \%$ & $11 \%$ & $7 \%$ \\
\hline Concentrating solar & $26.0 \%$ & 21637 & $7.7 \%$ & & $4 \%$ & $13 \%$ & $9 \%$ \\
\hline
\end{tabular}

Source: authors' calculations.

Table A15

\begin{tabular}{|c|c|c|c|c|c|c|}
\hline \multicolumn{7}{|l|}{ Clover } \\
\hline 2014/15 electricity consumption (MWh) & 89849 & & & & & \\
\hline \multirow{2}{*}{$\begin{array}{l}\text { Energy intensity } \\
\text { Technology }\end{array}$} & $2 \%$ & & & & & \\
\hline & $\begin{array}{l}\text { Capacity of } \\
\text { plant }\end{array}$ & $\begin{array}{l}\text { MWH } \\
\text { produced p.a }\end{array}$ & $\begin{array}{l}\text { \% of total } \\
\text { demand }\end{array}$ & Base case IRR & $\begin{array}{l}\text { High } \\
\text { scenario IRR }\end{array}$ & $\begin{array}{l}\text { Moderate } \\
\text { scenario IRR }\end{array}$ \\
\hline Wind $(10 \times 2 \mathrm{MW})$ & $15.0 \%$ & 25097 & $27.9 \%$ & $24 \%$ & $32 \%$ & $28 \%$ \\
\hline Wind $(25 \times 2 \mathrm{MW})$ & $15.0 \%$ & 62744 & $69.8 \%$ & $21 \%$ & $30 \%$ & $26 \%$ \\
\hline Solar PV & $26.0 \%$ & 22320 & $24.8 \%$ & $20 \%$ & $28 \%$ & $24 \%$ \\
\hline Concentrating solar & $26.0 \%$ & 21637 & $24.1 \%$ & $23 \%$ & $32 \%$ & $27 \%$ \\
\hline
\end{tabular}

Source: authors' calculations.

Table A16

\begin{tabular}{|c|c|c|c|c|c|c|}
\hline \multicolumn{7}{|l|}{ Pioneer Foods } \\
\hline 2014/15 electricity consumption (MWh) & 266172 & & & & & \\
\hline Energy intensity & $2 \%$ & & & & & \\
\hline Technology & $\begin{array}{l}\text { Capacity of } \\
\text { plant }\end{array}$ & $\begin{array}{l}\text { MWH } \\
\text { produced p.a }\end{array}$ & $\begin{array}{l}\% \text { of total } \\
\text { demand }\end{array}$ & Base case IRR & $\begin{array}{l}\text { High } \\
\text { scenario IRR }\end{array}$ & $\begin{array}{l}\text { Moderate } \\
\text { scenario IRR }\end{array}$ \\
\hline Wind $(10 \times 2 \mathrm{MW})$ & $15.0 \%$ & 25097 & $9.4 \%$ & $11 \%$ & $20 \%$ & $16 \%$ \\
\hline Wind $(25 \times 2 \mathrm{MW})$ & $15.0 \%$ & 62744 & $23.6 \%$ & $8 \%$ & $17 \%$ & $13 \%$ \\
\hline Solar PV & $26.0 \%$ & 22320 & $8.4 \%$ & $8 \%$ & $16 \%$ & $12 \%$ \\
\hline Concentrating solar & $26.0 \%$ & 21637 & $8.1 \%$ & $10 \%$ & $18 \%$ & $14 \%$ \\
\hline
\end{tabular}

Source: authors' calculations. 
Table A17

\begin{tabular}{|c|c|c|c|c|c|c|}
\hline \multicolumn{7}{|l|}{ Distell } \\
\hline 2014/15 electricity consumption (MWh) & 82793 & & & & & \\
\hline Energy intensity & $2 \%$ & & & & & \\
\hline Technology & $\begin{array}{l}\text { Capacity of } \\
\text { plant }\end{array}$ & $\begin{array}{l}\text { MWH } \\
\text { produced p.a }\end{array}$ & $\begin{array}{l}\text { \% of total } \\
\text { demand }\end{array}$ & Base case IRR & $\begin{array}{l}\text { High } \\
\text { scenario IRR }\end{array}$ & $\begin{array}{l}\text { Moderate } \\
\text { scenario IRR }\end{array}$ \\
\hline Wind $(10 \times 2 \mathrm{MW})$ & $15.0 \%$ & 25097 & $30.3 \%$ & $65 \%$ & $70 \%$ & $68 \%$ \\
\hline Wind $(25 \times 2 \mathrm{MW})$ & $15.0 \%$ & 62744 & $75.8 \%$ & $77 \%$ & $84 \%$ & $80 \%$ \\
\hline Solar PV & $26.0 \%$ & 22320 & $27.0 \%$ & $82 \%$ & $89 \%$ & $85 \%$ \\
\hline Concentrating solar & $26.0 \%$ & 21637 & $26.1 \%$ & $90 \%$ & $98 \%$ & $94 \%$ \\
\hline
\end{tabular}

Source: authors' calculations.

Table A18

\begin{tabular}{|c|c|c|c|c|c|c|}
\hline \multicolumn{7}{|l|}{ Nampak } \\
\hline 2014/15 electricity consumption (MWh) & 509385 & & & & & \\
\hline Energy intensity & $6 \%$ & & & & & \\
\hline Technology & $\begin{array}{l}\text { Capacity of } \\
\text { plant }\end{array}$ & $\begin{array}{l}\text { MWH } \\
\text { produced p.a }\end{array}$ & $\begin{array}{l}\% \text { of total } \\
\text { demand }\end{array}$ & Base case IRR & $\begin{array}{l}\text { High } \\
\text { scenario IRR }\end{array}$ & $\begin{array}{l}\text { Moderate } \\
\text { scenario IRR }\end{array}$ \\
\hline Wind (10 x $2 \mathrm{MW})$ & $15.0 \%$ & 25097 & $4.9 \%$ & $22 \%$ & $31 \%$ & $27 \%$ \\
\hline Wind $(25 \times 2 M W)$ & $15.0 \%$ & 62744 & $12.3 \%$ & $20 \%$ & $29 \%$ & $24 \%$ \\
\hline Solar PV & $26.0 \%$ & 22320 & $4.4 \%$ & $19 \%$ & $27 \%$ & $23 \%$ \\
\hline Concentrating solar & $26.0 \%$ & 21637 & $4.2 \%$ & $22 \%$ & $30 \%$ & $26 \%$ \\
\hline
\end{tabular}

Source: authors' calculations.

Table A19

\begin{tabular}{|c|c|c|c|c|c|c|}
\hline \multicolumn{7}{|l|}{ Nedbank } \\
\hline 2014/15 electricity consumption (MWh) & 165273 & & & & & \\
\hline Energy intensity & $1 \%$ & & & & & \\
\hline Technology & $\begin{array}{l}\text { Capacity of } \\
\text { plant }\end{array}$ & $\begin{array}{l}\text { MWH } \\
\text { produced p.a }\end{array}$ & $\begin{array}{l}\text { \% of total } \\
\text { demand }\end{array}$ & Base case IRR & $\begin{array}{l}\text { High } \\
\text { scenario IRR }\end{array}$ & $\begin{array}{l}\text { Moderate } \\
\text { scenario IRR }\end{array}$ \\
\hline Wind $(10 \times 2 \mathrm{MW})$ & $15.0 \%$ & 25097 & $15.2 \%$ & $15 \%$ & $24 \%$ & $20 \%$ \\
\hline Wind $(25 \times 2 M W)$ & $15.0 \%$ & 62744 & $38.0 \%$ & $12 \%$ & $21 \%$ & $17 \%$ \\
\hline Solar PV & $26.0 \%$ & 22320 & $13.5 \%$ & $12 \%$ & $20 \%$ & $16 \%$ \\
\hline Concentrating solar & $26.0 \%$ & 21637 & $13.1 \%$ & $14 \%$ & $22 \%$ & $18 \%$ \\
\hline
\end{tabular}

Source: authors' calculations.

Table A20

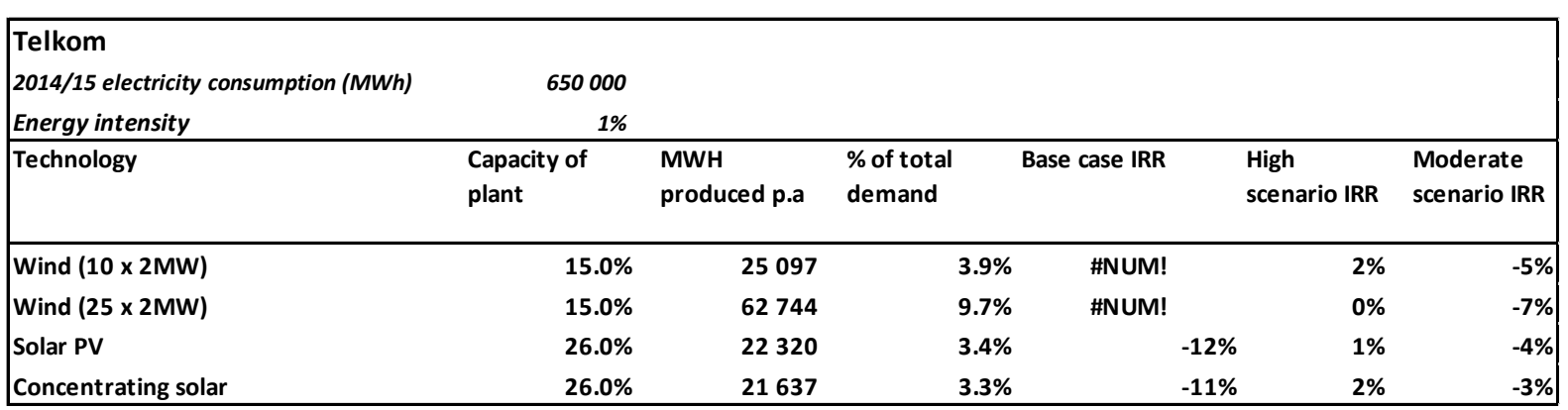

Source: authors' calculations. 
Table A21

\begin{tabular}{|c|c|c|c|c|c|c|c|}
\hline Tsogo Sun & & & & & & & \\
\hline 2014/15 electricity consumption (MWh) & 255000 & & & & & & \\
\hline Energy intensity & $2 \%$ & & & & & & \\
\hline Technology & $\begin{array}{l}\text { Capacity of } \\
\text { plant }\end{array}$ & $\begin{array}{l}\text { MWH } \\
\text { produced p.a }\end{array}$ & $\begin{array}{l}\% \text { of total } \\
\text { demand }\end{array}$ & Base case IRR & & $\begin{array}{l}\text { High } \\
\text { scenario IRR }\end{array}$ & $\begin{array}{l}\text { Moderate } \\
\text { scenario IRR }\end{array}$ \\
\hline Wind $(10 \times 2 \mathrm{MW})$ & $15.0 \%$ & 25097 & $9.8 \%$ & & $0 \%$ & $12 \%$ & $7 \%$ \\
\hline Wind $(25 \times 2 M W)$ & $15.0 \%$ & 62744 & $24.6 \%$ & & $-2 \%$ & $9 \%$ & $4 \%$ \\
\hline Solar PV & $26.0 \%$ & 22320 & $8.8 \%$ & & $0 \%$ & $\mathbf{9 \%}$ & $5 \%$ \\
\hline Concentrating solar & $26.0 \%$ & 21637 & $8.5 \%$ & & $1 \%$ & $10 \%$ & $6 \%$ \\
\hline
\end{tabular}

Source: authors' calculations.

Table A22

\begin{tabular}{|c|c|c|c|c|c|c|}
\hline \multicolumn{7}{|l|}{ Netcare } \\
\hline 2014/15 electricity consumption (MWh) & 309733 & & & & & \\
\hline \multirow{2}{*}{$\begin{array}{l}\text { Energy intensity } \\
\text { Technology }\end{array}$} & $2 \%$ & & & & & \\
\hline & $\begin{array}{l}\text { Capacity of } \\
\text { plant }\end{array}$ & $\begin{array}{l}\text { MWH } \\
\text { produced p.a }\end{array}$ & $\begin{array}{l}\text { \% of total } \\
\text { demand }\end{array}$ & Base case IRR & $\begin{array}{l}\text { High } \\
\text { scenario IRR }\end{array}$ & $\begin{array}{l}\text { Moderate } \\
\text { scenario IRR }\end{array}$ \\
\hline Wind $(10 \times 2 \mathrm{MW})$ & $15.0 \%$ & 25097 & $8.1 \%$ & $15 \%$ & $24 \%$ & $20 \%$ \\
\hline Wind $(25 \times 2 \mathrm{MW})$ & $15.0 \%$ & 62744 & $20.3 \%$ & $12 \%$ & $21 \%$ & $17 \%$ \\
\hline Solar PV & $26.0 \%$ & 22320 & $7.2 \%$ & $12 \%$ & $19 \%$ & $16 \%$ \\
\hline Concentrating solar & $26.0 \%$ & 21637 & $7.0 \%$ & $14 \%$ & $22 \%$ & $18 \%$ \\
\hline
\end{tabular}

Technologies with IRRs greater than 12 are highlighted in green. If plant capacity falls below 55 per cent, i.e. turns red, then the technology is unviable.

Source: authors' calculations.

Table A23: Own-generation potential with 100 per cent wheeling charges

\begin{tabular}{|c|c|c|c|}
\hline & Base & High & Moderate \\
\hline Sibanye & 3926856 & 3926856 & 3926856 \\
\hline Harmony Gold & - & - & - \\
\hline AngloPlat & 4424627 & 4424627 & 4424627 \\
\hline Lonmin & - & - & - \\
\hline Implats & - & 250974 & - \\
\hline Kumba Iron Ore & 250974 & 62744 & 62744 \\
\hline Evraz Highveld Steel & - & - & - \\
\hline Arcelor Mittal & 3429086 & 3429086 & 3429086 \\
\hline Hulamin & 250974 & 250974 & 250974 \\
\hline PPC & - & - & - \\
\hline AECI & 250974 & 250974 & 250974 \\
\hline Transnet & 3484394 & 3484394 & 3484394 \\
\hline Astral Foods & - & - & - \\
\hline Clover & 22320 & 22320 & 22320 \\
\hline Pioneer Foods & - & 25097 & 21637 \\
\hline Distell & 62744 & 62744 & 62744 \\
\hline Nampak & 62744 & 62744 & 62744 \\
\hline Nedbank & - & 25097 & 22320 \\
\hline Telkom & - & - & - \\
\hline Tsogo Sun & - & - & - \\
\hline Netcare & 21637 & 25097 & 25097 \\
\hline Total (MWH) & 16187330 & 16303728 & 16046517 \\
\hline Eskom sales (2013/14) GWH & 217903 & 217903 & 217903 \\
\hline Eskom sales $(2013 / 14) \mathrm{MWH}$ & 217903000 & 217903000 & 217903000 \\
\hline$\%$ of Eskom sales & $7.4 \%$ & $7.5 \%$ & $7.4 \%$ \\
\hline
\end{tabular}

Source: authors' calculations. 
Table A24: Own-generation potential with 60 per cent wheeling charges

\begin{tabular}{|c|c|c|c|}
\hline & Base & High & Moderate \\
\hline Sibanye & 3926856 & 3976295 & 3926856 \\
\hline Harmony Gold & - & 1682796 & - \\
\hline AngloPlat & 4424627 & 4424627 & 4424627 \\
\hline Lonmin & - & - & - \\
\hline Implats & - & 1682796 & 1682796 \\
\hline Kumba Iron Ore & 250974 & 250974 & 250974 \\
\hline Evraz Highveld Steel & - & - & - \\
\hline Arcelor Mittal & 3429086 & 3494320 & 3494320 \\
\hline Hulamin & 250974 & 250974 & 250974 \\
\hline PPC & - & - & - \\
\hline AECI & 250974 & 250974 & 250974 \\
\hline Transnet & 3484394 & 3484394 & 3484394 \\
\hline Astral Foods & - & - & - \\
\hline Clover & 25097 & 25097 & 25097 \\
\hline Pioneer Foods & - & 25097 & 25097 \\
\hline Distell & 62744 & 62744 & 62744 \\
\hline Nampak & 62744 & 62744 & 62744 \\
\hline Nedbank & 21637 & 25097 & 25097 \\
\hline Telkom & - & - & - \\
\hline Tsogo Sun & - & - & - \\
\hline Netcare & 25097 & 62744 & 25097 \\
\hline Total (MWH) & 16215204 & 19761673 & 17991791 \\
\hline Eskom sales (2013/14) GWH & 217903 & 217903 & 217903 \\
\hline Eskom sales (2013/14) MWH & 217903000 & 217903000 & 217903000 \\
\hline$\%$ of Eskom sales & $7.4 \%$ & $9.1 \%$ & $8.3 \%$ \\
\hline
\end{tabular}

Source: authors' calculations.

Table A25: Own-generation potential with zero per cent wheeling charges

\begin{tabular}{|c|c|c|c|}
\hline & Base & High & Moderate \\
\hline Sibanye & 3926856 & 3976295 & 3976295 \\
\hline Harmony Gold & - & 1682796 & 1682796 \\
\hline AngloPlat & 4424627 & 4424627 & 4424627 \\
\hline Lonmin & - & 250947 & 250974 \\
\hline Implats & 1682796 & 1682796 & 1682796 \\
\hline Kumba Iron Ore & 250947 & 250947 & 250974 \\
\hline Evraz Highveld Steel & - & 1385832 & - \\
\hline Arcelor Mittal & 3494320 & 3494320 & 3494320 \\
\hline Hulamin & 250947 & 250947 & 250974 \\
\hline PPC & - & - & - \\
\hline AECI & 250947 & 250947 & 250974 \\
\hline Transnet & 3484394 & 3484394 & 3484394 \\
\hline Astral Foods & - & 62744 & - \\
\hline Clover & 62744 & 62744 & 62744 \\
\hline Pioneer Foods & 25097 & 62744 & 62744 \\
\hline Distell & 62744 & 62744 & 62744 \\
\hline Nampak & 62744 & 62744 & 62744 \\
\hline Nedbank & 62744 & 62744 & 62744 \\
\hline Telkom & - & - & - \\
\hline Tsogo Sun & - & 25097 & - \\
\hline Netcare & 62744 & 62744 & 62744 \\
\hline Total (MWH) & 18104651 & 21599153 & 20125588 \\
\hline Eskom sales (2013/14) GWH & 217903 & 217903 & 217903 \\
\hline Eskom sales (2013/14) MWH & 217903000 & 217903000 & 217903000 \\
\hline$\%$ of Eskom sales & $8.3 \%$ & $9.9 \%$ & $9.2 \%$ \\
\hline
\end{tabular}

Source: authors' calculations. 
Table A26: Sensitivity of own-generation potential to NPV percentage: moderate scenario number, wheeling charges, build 2015-16, Energy Information Administration forecast

\begin{tabular}{|c|c|c|c|c|}
\hline & 9 & 12 & 15 & 18 \\
\hline Sibanye & 3976295 & 3976295 & 3976295 & 3926856 \\
\hline Harmony Gold & 1682796 & 1682796 & 1682796 & - \\
\hline AngloPlat & 4424627 & 4424627 & 4424627 & 4424627 \\
\hline Lonmin & 250974 & 250974 & - & - \\
\hline Implats & 1682796 & 1682796 & 1682796 & 1682796 \\
\hline Kumba Iron Ore & 250974 & 250974 & 250974 & 250974 \\
\hline Evraz Highveld Steel & - & - & - & - \\
\hline Arcelor Mittal & 3494320 & 3494320 & 3494320 & 3429086 \\
\hline Hulamin & 250974 & 250974 & 250974 & 250974 \\
\hline PPC & - & - & - & - \\
\hline $\mathrm{AECl}$ & 250974 & 250974 & 250974 & 250974 \\
\hline Transnet & 3484394 & 3484394 & 3484394 & 3484394 \\
\hline Astral Foods & 25097 & - & - & - \\
\hline Clover & 62744 & 62744 & 62744 & 62744 \\
\hline Pioneer Foods & 62744 & 62744 & 25097 & - \\
\hline Distell & 62744 & 62744 & 62744 & 62744 \\
\hline Nampak & 62744 & 62744 & 62744 & 62744 \\
\hline Nedbank & 62744 & 62744 & 62744 & 25097 \\
\hline Telkom & - & - & - & - \\
\hline Tsogo Sun & - & - & - & - \\
\hline Netcare & 62744 & 62744 & 62744 & 25097 \\
\hline Total (MWH) & 20150683 & 20125585 & 19836965 & 17939106 \\
\hline Eskom sales $(2013 / 14) \mathrm{C}$ & 217903 & 217903 & 217903 & 217903 \\
\hline Eskom sales $(2013 / 14) n$ & 217903000 & 217903000 & 217903000 & 217903000 \\
\hline$\%$ of Eskom sales & $9.2 \%$ & $9.2 \%$ & $9.1 \%$ & $8.2 \%$ \\
\hline
\end{tabular}

Source: authors' calculations. 